\title{
REGIC: TRAJETÓRIA, VARIAÇÕES E HIERARQUIA URBANA EM 2018
}

Rosa Moura

Liria Nagamine

Gustavo Ferreira
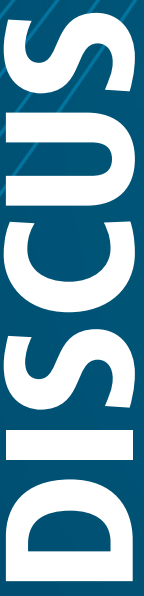

$\frac{1}{2}$

$\frac{0}{1}$

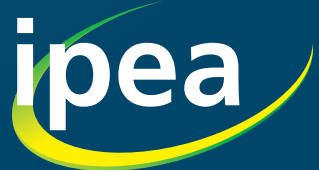





\section{TEXTO PARA DISCUSSÃO}

Brasília, junho de 2021

\section{REGIC: TRAJETÓRIA, VARIAÇÕES E HIERARQUIA URBANA EM $2018^{1}$}

Rosa Moura ${ }^{2}$

Liria Nagamine ${ }^{3}$

Gustavo Ferreira ${ }^{4}$

1. Este texto é produto da pesquisa Fronteiras do Brasil: uma avaliação de política pública, desenvolvida na Diretoria de Estudos e Políticas Regionais, Urbanas e Ambientais (Dirur) do Ipea. Os autores agradecem à leitura atenta, aos comentários e às sugestões dos pareceristas Ernesto Pereira Galindo e Vanessa Gapriotti Nadalin, que possibilitaram ajustes fundamentais à estrutura e ao conteúdo do texto eximindo-os de qualquer responsabilidade quanto a possíveis erros e/ou omissões. 2. Profissional sênior na Dirur/lpea.E-mail: <rosa.silva@ipea.gov.br>.

3. Pesquisadora na Dirur/lpea.E-mail: <liria.nagamine@ipea.gov.br>.

4. Pesquisador na Dirur/lpea.E-mail:<gustavo.ferreira@ipea.gov.br>. 


\section{Governo Federal}

Ministério da Economia

Ministro Paulo Guedes

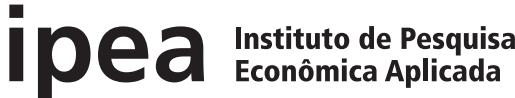

Fundação pública vinculada ao Ministério da Economia, o Ipea fornece suporte técnico e institucional às ações governamentais - possibilitando a formulação de inúmeras políticas públicas e programas de desenvolvimento brasileiros - e disponibiliza, para a sociedade, pesquisas e estudos realizados por seus técnicos.

Presidente

Carlos von Doellinger

Diretor de Desenvolvimento Institucional

Manoel Rodrigues Junior

Diretora de Estudos e Políticas do Estado, das Instituições e da Democracia

Flávia de Holanda Schmidt

Diretor de Estudos e Políticas Macroeconômicas José Ronaldo de Castro Souza Júnior

Diretor de Estudos e Políticas Regionais, Urbanas e Ambientais

Nilo Luiz Saccaro Júnior

Diretor de Estudos e Políticas Setoriais de Inovação e Infraestrutura

André Tortato Rauen

Diretora de Estudos e Políticas Sociais Lenita Maria Turchi

Diretor de Estudos e Relações Econômicas e Políticas Internacionais

Ivan Tiago Machado Oliveira

Assessor-chefe de Imprensa e Comunicação André Reis Diniz

Ouvidoria: http://www.ipea.gov.br/ouvidoria URL: http://www.ipea.gov.br

\section{Texto para Discussão}

Publicação seriada que divulga resultados de estudos e pesquisas em desenvolvimento pelo Ipea com o objetivo de fomentar o debate e oferecer subsídios à formulação e avaliação de políticas públicas.

(C) Instituto de Pesquisa Econômica Aplicada - ipea 2021

Texto para discussão / Instituto de Pesquisa Econômica Aplicada.- Brasília : Rio de Janeiro : Ipea , 1990-

ISSN 1415-4765

1.Brasil. 2.Aspectos Econômicos. 3.Aspectos Sociais. I. Instituto de Pesquisa Econômica Aplicada.

CDD 330.908

As publicações do Ipea estão disponíveis para download gratuito nos formatos PDF (todas) e EPUB (livros e periódicos).

Acesse: http://www.ipea.gov.br/portal/publicacoes

As opiniões emitidas nesta publicação são de exclusiva e inteira responsabilidade dos autores, não exprimindo, necessariamente, o ponto de vista do Instituto de Pesquisa Econômica Aplicada ou do Ministério da Economia.

É permitida a reprodução deste texto e dos dados nele contidos, desde que citada a fonte. Reproduções para fins comerciais são proibidas. 


\section{SUMÁRIO}

SINOPSE

ABSTRACT

1 INTRODUÇÃO 7

2 A IMPORTÂNCIA DAS PESQUISAS SOBRE HIERARQUIA URBANA E REGIÕES DE INFLUÊNCIA DAS CIDADES. . .8

3 A TRAJETÓRIA DA LINHA DE PESQUISA NO IBGE. 17

4 O COMPORTAMENTO DA REDE DE CIDADES 33

5 AS RELAÇÕES INTERNACIONAIS DA REDE URBANA 57

6 CONSIDERAÇÕES FINAIS 64

REFERÊNCIAS 



\section{SINOPSE}

Neste Texto para Discussão (TD), elabora-se uma síntese da trajetória da linha de pesquisas sobre as Regióes de Influência das Cidades (Regic) brasileiras, desenvolvida pelo Instituto Brasileiro de Geografia e Estatística (IBGE), cujo conteúdo prima pela longevidade, sistematicidade e atualidade de pesquisas complexas que expressam a rede urbana brasileira desde os anos 1960. Além de historiar essa trajetória, destacam-se alguns resultados e avanços da pesquisa mais recente, disponibilizados em 2018. Ressalta-se a importância dos estudos sobre a hierarquia urbana e as regióes de influência das cidades, e se tecem consideraçôes gerais sobre os aspectos históricos e metodológicos da pesquisa, com ênfase na qualidade e facilidade de acesso às informaçóes produzidas. $\mathrm{Na}$ construçáo histórica, aborda-se que o aprimoramento dos procedimentos operacionais não comprometeu a comparabilidade metodológica nem os resultados, o que garantiu acompanhar a evolução, ao longo do tempo, do posicionamento de cada cidade na escala da rede urbana. Voltando-se à estruturação da rede urbana, este estudo apresenta os resultados de um exercício que buscou demarcar as mudanças e permanências das cidades na escala hierárquica ao longo do período analisado. Constataram-se, também, importantes mudanças na variação dos níveis de centralidade, relativas à ascensão ou queda nos reescalonamentos ao longo do período. As ligaçóes internacionais das cidades da faixa de fronteira terrestre e as conexóes internacionais de longa distância de todas as cidades também mereceram destaque no texto que se apresenta, pelo ineditismo na série das pesquisas consideradas. Por fim, renova-se a importância da pesquisa e a firmeza do Instituto Brasileiro de Geografia e Estatística (IBGE) na produção de uma série de elevada qualidade e constante periodicidade. Salienta-se o quanto seus resultados apontam para a urgência de uma reflexão sobre o pacto federativo, posto que a dinâmica socioespacial cada vez mais ignora limites e fronteiras.

Palavras-chave: Regic; hierarquia urbana; rede urbana; regióes de influência das cidades.

\section{ABSTRACT}

In this text for discussion, a synthesis of the trajectory of the line of research on the Regions of Influence of Brazilian Cities, developed by IBGE, whose content excels in the longevity, systematcity and timeliness of complex research that expresses the Brazilian urban network since the 1960s, is elaborated. In addition to history of this trajectory, some results and advances of the most recent research, available in 2018, are highlighted in the text. It highlights the importance of studies on urban hierarchy and regions of influence of cities, and general considerations are made about the historical 
and methodological aspects of research, with emphasis on quality and ease of access to the information produced. In the historical construction, it approaches that the improvement of operational procedures did not compromise methodological comparability and results, which ensured to follow the evolution, over time, of the positioning of each city on the scale of the urban network. Returning to the structuring of the urban network, the text presents the results of an exercise that sought to demarcate the changes and permanence of cities in the hierarchical scale throughout the analyzed period. There were also important changes in the variation of centrality levels, related to the rise or fall in rescheduling over the period. The international connections of the cities of the land border strip and the long-distance international connections of all cities also deserved to be highlighted in the text that is presented, for the novelty in the series of researches considered. Finally, the importance of the research and the firmness of IBGE in the production of a series of high quality and constant periodicity is renewed. It is emphasized how much its results point to the urgency of a reflection on the federative pact, since the socio-spatial dynamics increasingly ignore snow and borders.

Keywords: Regic; urban hierarchy; urban network; regions of influence of cities. 


\section{INTRODUÇÃO}

Este texto, que oferecemos para discussão, traz uma síntese da história de uma bem-sucedida linha de pesquisas sobre as Regióes de Influência das Cidades (Regic) brasileiras, desenvolvida pelo Instituto Brasileiro de Geografia e Estatística (IBGE). As principais referências utilizadas foram as publicações decorrentes dos estudos de 2007 e 2018 (IBGE, 2008; 2020a), sobre as quais descreve a trajetória das pesquisas e da rede urbana do Brasil, destacando aspectos sobre a variação das classificaçóes entre os cinco períodos de análise e as mudanças nos procedimentos operacionais, sempre introduzidos com a finalidade de ajustar-se às transformaçóes sociais e econômicas do espaço urbano em suas relaçóes internas ao território brasileiro e, mais recentemente, em suas conexôes internacionais.

As leituras remetem, indubitavelmente, a elogiar o relevante empenho institucional do IBGE em propor e manter com sistematicidade a atualidade de pesquisas complexas, cujos resultados são subsídios fundamentais a estudos acadêmicos, à formulação de políticas públicas e à tomada de decisóes quanto a investimentos e alocação de serviços públicos e privados que garantam à população as mais adequadas condições de acesso. A compreensão histórica da rede urbana, viabilizada por essa série de estudos, reiterando palavras da própria instituição, "constitui uma abordagem fundamental para a compreensão da geografia do País, uma vez que estabelece critérios para a qualificação das Cidades e das relaçôes entre elas, revelando eixos de integração no território e padróes diferenciados de distribuição de centralidades urbanas” (IBGE, 2020a, p. 9).

O texto está estruturado em seis seções que contemplam os aspectos históricos e metodológicos quanto à importância das pesquisas sobre a hierarquia urbana e as regiôes de influência das cidades na formulação de políticas públicas e, em especial, à organização de redes hierarquizadas de atendimento a serviços especializados, sobre o que traz o exemplo recente da pandemia do novo coronavírus (seção 2). Descreve-se a trajetória da linha de pesquisa no IBGE de 1966 a 2018, seus aprimoramentos metodológicos e operacionais, acentuando a relevância dos arranjos populacionais (APs) como unidades de pesquisa, e a construção histórica e comparabilidade das escalas de classificação (seção 3). Na sequência, se volta propriamente ao comportamento da rede urbana, focando as mudanças e permanências em sua organização ao longo do período analisado e a variação nos níveis de centralidade, em que trata da distribuição territorial 
das mudanças e permanências e de detalhes sobre a variação dos municípios a partir de 2007 (seção 4). Evidenciam-se dois levantamentos inéditos na pesquisa Regic, relativos às relaçóes internacionais da rede urbana; suas ligaçôes internacionais a partir da faixa de fronteira terrestre e suas conexôes de longa distância (seção 5). Nas consideraçóes finais (seção 6), renovam-se elogios ao trabalho e oferecem-se pequenas sugestôes de ajustes nas informaçóes disponibilizadas ou realização de estudos complementares.

\section{A IMPORTÂNCIA DAS PESQUISAS SOBRE HIERARQUIA URBANA E REGIÕES DE INFLUÊNCIA DAS CIDADES}

O IBGE, desde os anos 1960, investiga periodicamente a hierarquia dos centros urbanos e suas respectivas regióes de influência, publicando resultados que compóem a série mais completa e longeva sobre a rede urbana entre os países sul-americanos. Nesta seção, será realizada uma abordagem sobre um pouco da história da pesquisa Regic, realizada pelo IBGE, apontando sua consolidação pela relevância que assume na formulação de políticas públicas urbanas, metropolitanas e regionais. Mais que relevância, aponta-se sua imprescindibilidade, como constatada no trato da pandemia do novo coronavírus.

\subsection{Uma série que se consolida}

A série que compõe a pesquisa Regic desenvolve uma trajetória que se inicia nos anos 1960, com o estudo Esboço preliminar da divisäo do Brasil em espaços homogêneos e espaços polarizados (IBGE, 1967), seguido pela pesquisa realizada em 1966, publicada em Divisão do Brasil em regiōes funcionais urbanas (IBGE, 1972). A partir de então, as pesquisas que se sucederam foram intituladas como Regióes de Influência das Cidades e ocorreram em 1978 (IBGE, 1987); 1993 (IBGE, 2000); 2007 (IBGE, 2008); e 2018 (IBGE, 2020a).

Essas pesquisas tiveram como fio condutor a teoria dos fluxos centrais de Taylor (2001), entre outros do autor, que incorpora a teoria das localidades centrais de Christaller (1966) a aportes teóricos próprios. Os resultados dessas pesquisas, a cada publicação, atualizam informaçóes sobre a organização da rede urbana nacional e sua escala hierárquica, além de consolidarem um histórico da distribuição e trajetória das classes de centralidades exercidas pelos municípios brasileiros, e identificarem suas regiôes de influência. Conhecer a organizaçáo da rede urbana, as regióes de influência das cidades e os reescalonamentos em sua hierarquia é imprescindível para a formulação de políticas públicas com incidência no território. 
Além dessa série do IBGE, há disponível um conjunto de estudos que asseguram análises da evolução da rede urbana brasileira desde os anos 1960. Egler et al. (2011) fazem uma síntese das principais referências, com destaque à coletânea organizada por Gonçalves, Brandão e Galvão (2003), além de Egler (2006; 2008), Corrêa (2004), Lemos, Diniz e Guerra (1999) e Diniz (2002), que discutem a importância das pesquisas sobre rede de cidades para as políticas públicas de gestão do território. Somam-se a esses os estudos realizados no âmbito do governo federal, como: Configuraçâo atual e tendências da rede urbana do Brasil (Ipea, 2002), realizado conjuntamente pelo Ipea, IBGE e Núcleo de Economia Social, Urbana e Regional da Universidade Estadual de Campinas (Nesur/ Unicamp), com apoio de instituiçôes estaduais de pesquisa; Dimensão territorial para o planejamento, empreendido pelo Centro de Gestão e Estudos Estratégicos (CGEE) (Brasil, 2008); e Dinâmica urbana dos estados (Pereira e Furtado, 2011), elaborado em rede com instituiçóes estaduais de pesquisa, coordenado pelo Ipea (Ipea, 2016). ${ }^{1}$

Egler (2015, p. 47) destaca a relevância de se analisar e acompanhar a evolução da rede de cidades, por ser ela uma manifestação concreta da integração territorial de uma determinada regiáo. "Pode-se afirmar que o estágio de desenvolvimento e de complexidade da rede urbana manifesta a extensão e a profundidade do processo de integraçáo produtiva e financeira entre as regiôes e as naçôes".

Embora a atividade econômica no Brasil venha sofrendo profundas transformaçôes, particularmente após 1970, com dinâmicas de desconcentração, relocalização e diversificação de atividades secundárias e terciárias, em paralelo à reprimarização da economia, a estrutura urbana brasileira vem se reforçando sobre o mesmo conjunto de centralidades principais, com poucos reposicionamentos. $\mathrm{O}$ que vem mudando com mais intensidade são os papéis e valores desempenhados pelas cidades e suas respectivas regiōes, as funções

1. "À época da construção da série Caracterização e tendências da rede urbana do Brasil, foram envolvidas vinte instituições, entre estaduais e federais, incluindo Ipea, IBGE, Nesur/IE/Unicamp, Superintendência do Desenvolvimento da Amazônia (Sudam) e Superintendência do Desenvolvimento do Nordeste (Sudene), assim como instituições públicas de pesquisa de oito Unidades da Federação (UFs). Mais recentemente, o estudo Dinâmica urbano-regional: rede urbana e suas interfaces (Pereira e Furtado, 2011) contou com a participação de onze instituições de dez UFs. Ao mesmo tempo, estava em andamento a construção de uma rede que já contava com acordo de cooperação com 21 instituições de dezenove UFs" (Ipea, 2016, p. 10). 
urbanas $^{2}$ e interaçóes espaciais entre os centros, e as morfologias, pois se operam mudanças no conteúdo e nas formas de uso do espaço, combinando continuidade e descontinuidade territorial, adensamentos concentrados e fragmentos dispersos pelo território. Articulaçóes verticais coexistem com horizontais, diferentes processos políticos, sociais e econômicos operam mudanças nas formas de relacionamentos e no jogo de disputas territoriais, colocando as redes urbanas em constante transformação e reposicionamentos em suas hierarquias, ${ }^{3}$ o que não só justificam como exigem estudos contínuos ou sucessivos.

Neste início de século, com duas décadas passadas, o urbano brasileiro apresenta como tônica a metropolização do espaço, cujas centralidades principais, as metrópoles e capitais regionais, estruturam seus entornos e comandam a integração nacional e a inserção do país na divisão regional do trabalho. As principais formas das cidades neste estágio da urbanização, conforme antecipado em Ipea (2016), correspondem a grandes aglomeraçóes ou espaços expandidos de concentração, que assumem uma dimensão regional. Favorecidos por intensa mobilidade pendular, esses espaços configuram arranjos espaciais, adensados e contínuos nos interiores e descontínuos em seus vetores de expansão, muitos com natureza urbano-regional. Articulam-se a esses espaços centralidades intermediárias (centros sub-regionais e centros de zona) no interior do território, que se consolidam e reforçam a rede de cidades e a hierarquia de centros, correspondendo às porções com maior intensidade da urbanização. $\mathrm{O}$ mesmo urbano em metropolização faz emergir centralidades em áreas de expansão da fronteira econômica (mineração e grandes projetos do agronegócio, de infraestrutura econômica e integração regional), assim como arranjos transfronteiriços, que por vezes estendem-se em território de três países. Pequenos centros que oferecem alternativas de emprego e renda, bem como possibilidades de beneficiamento da produção, também podem ter sua importância redefinida na rede de cidades.

2. Particularmente às funções urbanas, retoma-se Ipea (2016, p. 31) que, "de acordo com Corrêa (1989), a ideia de função urbana remete ao conceito de divisão territorial do trabalho: se esta não existisse, não haveria diferenciação funcional entre cidades; remete, ainda, ao conceito de processo e de estrutura: a função urbana é a realização de um processo que emana de uma estrutura social. E nos leva ainda ao conceito de forma espacial: a função necessita de uma forma para se realizar a loja, a fábrica, a cidade, a rede urbana".

3. No urbano contemporâneo, como destacado em (Ipea, 2016, p. 31), "a hierarquia urbana se inscreve cada vez mais num contexto econômico internacional, que transforma a natureza das relações entre cidades e seus hinterlands, entre as cidades do mesmo nível e entre centros urbanos de diferentes categorias, tornando-se menos piramidal, dadas as relações de complementaridade entre aglomerações de mesmo nível. Esse processo de mundialização não implica que deixe de existir uma estrutura hierarquizada de relações e articulações entre os diversos centros dentro do território nacional, mas que essas relações estão cada vez mais mediatizadas por novos determinantes". 
Portanto, uma rede urbana tanto reflete quanto reforça as características dos contextos políticos, econômicos e socioculturais do território, pois representa uma dimensão socioespacial, um elemento integrante da realidade em sua complexidade. Em constante mudança, cidade e rede urbana sofrem os efeitos e, ao mesmo tempo, promovem as transformaçōes estruturais que se procedem em diversas escalas e em diferentes tempos, e determinam a inserção e o reposicionamento das cidades na hierarquia urbana, pois alteram suas características físicas (tamanho, densidade e morfologia) e funcionais, assim como as interações espaciais, entre centros. Esse conjunto de mudanças transforma, por conseguinte, a própria rede urbana, sua estrutura, sua natureza, sua forma espacial e seu significado (Ipea, 2016, p. 30-31).

\subsection{A relevância da hierarquia urbana nas políticas públicas}

No âmbito de políticas públicas regionais, os resultados da pesquisa Regic e os estudos de rede urbana também podem ter papel relevante. A rede urbana brasileira, sua hierarquia de centralidades e regiôes de influência conformam o desenho do comando multi e transescalar dos serviços e das atividades urbanas do território e, sendo assim, refletem em grande medida o nível de integração dos seus sistemas produtivo, financeiro e sociocultural. A visão integrada das relaçóes entre polos, de suas regiốes de influência e da lógica de configuração que a rede permite identificar consiste em fonte de consistência para o planejamento de políticas públicas territoriais, principalmente regionais (Diniz, 2011; Egler et al., 2011). Além disso, uma leitura da rede associada à urbanização pode ser considerada como "síntese de um longo processo de mudança territorial do país, no qual a dinâmica e as alternativas de localizaçáo das atividades econômicas têm importante papel indutor, entendendo-se a urbanização como parte integrante dessas determinaçôes" (Ipea, 2002, p. 33).

Regionalmente, uma caracterização da rede urbana em maior detalhe, refinando-se a análise de seus núcleos e estruturas urbanas em escala sub-regional, permite açôes de interação e convergência entre a União, os estados e os municípios. Responde desta forma à formulação de políticas públicas interfederativas integradas para o desenvolvimento regional e sendo assim, capazes de atender a um dos objetivos fundamentais da República Federativa do Brasil, enunciado no art. 3o, inciso III, da Constituição. Qual seja, o de "erradicar a pobreza e a marginalização e reduzir as desigualdades sociais e regionais".

Tal é o pressuposto básico da Política Nacional de Desenvolvimento Regional (PNDR) desde a sua primeira versão, instituída pelo Decreto ํㅡ 6.047/2007, para cujo conteúdo contribuiu um arcabouço considerável de pesquisas, e a continuidade destas em estudos e debates sobre a caracterização, as tendências e aplicações práticas de seus 
conteúdos em políticas públicas, realizados por um leque de instituições públicas, entre as quais se destacam o Ipea em associação com o IBGE, conforme já citado, como também o estudo Dimensão territorial para o planejamento, elaborado pelo CGEE (Brasil, 2008). A compreensão da importância da relação entre centros e sua área de influência no âmbito de políticas públicas esteve assimilada nas proposiçôes originais dessa política, porém foi descartada em sua última versão e na lei que concerne à PNDR.

Brandão (2020a; 2020b) considera como ponto culminante desse processo de construção da política regional a realização da I Conferência Nacional de Desenvolvimento Regional (CNDR), em 19 de março de 2013, após conferências regionais e macrorregionais, num processo que contou com aproximadamente 13 mil participantes. Como resultado destaca-se o envio do Projeto de Lei (PL) no 375/2015 ao Congresso Nacional que, segundo palavras do autor, "transformaria a política regional em uma política de estado, e não de um governo" (Brandão, 2020a). Mesmo não aprovado, ressalta-se a importância dada por esse PL aos estudos da rede urbana, como subsídios à realização da PNDR, fruto de avançadas pesquisas de regionalização realizadas ao longo do tempo.

O projeto expunha como um dos quatro objetivos da PNDR "consolidar uma rede de cidades policêntrica, que contribua para a desconcentração e interiorização do desenvolvimento das regiốes e do País, fortalecendo centralidades em diferentes escalas geográficas", e sua consecução resultaria da definição de uma rede de cidades-polo prioritária. Tal definição seria realizada a partir de estudo técnico elaborado com as seguintes diretrizes: i) considerar a caracterização e as propostas da pesquisa Regióes de Influência de Cidades, do IBGE, e do estudo Dimensão territorial para o planejamento, da CGEE, e suas atualizaçóes; ii) incluir consulta a especialistas, formuladores de políticas, agentes públicos e lideranças regionais e locais; iii) tratar da rede de cidades-polo em múltiplas escalas geográficas; e iv) dar tratamento diferenciado às redes de cidades do semiárido brasileiro, da Amazônia legal e da faixa de fronteira. Previa ainda, no inciso segundo, a elaboraçáo de um plano de desenvolvimento da rede de cidades, com definição de metas concretas de fortalecimento dos polos, especialmente no que se refere à infraestrutura logística, à rede de banda larga e à oferta de serviços básicos, que ampliem sua capacidade em termos de polarização, comando e organização do território.

Na nova PNDR, aprovada pelo Decreto nº 9.810, de 30 de maio de 2019, somente restou o objetivo de consolidar uma rede policêntrica de cidades como "forma 
de considerar as especificidades de cada região" e não de "fortalecer centralidades em diferentes escalas geográficas", como no PL original, restringindo conceitualmente e modificando o significado sobre o tema. Restringiu-se também o grau de importância da função desse estudo para a redução das desigualdades regionais do país, na medida em que deixa de considerar componentes importantes para a distinção de conceitos e categorias de análise, em sua multi, inter e transescalaridade.

O Estatuto da Metrópole (Lei Federal no 13.089/2015) também reconhece a importância da pesquisa Regic em seu art. 2을 que comporta um relevante arcabouço conceitual sobre as categorias que compóem as unidades territoriais urbanas, entendidas como regiōes metropolitanas, aglomeraçóes urbanas e microrregióes, a serem instituídas pelos estados federados para o exercício de funçóes públicas de interesse comum. No inciso $\mathrm{V}$, desse artigo, encontra-se com clareza o conceito de:

V - metrópole: espaço urbano com continuidade territorial que, em razão de sua população e relevância política e socioeconômica, tem influência nacional ou sobre uma região que configure, no mínimo, a área de influência de uma capital regional, conforme os critérios adotados pela Fundação Instituto Brasileiro de Geografia e Estatística - IBGE (Brasil, 2015).

Se por um lado, o conceito referenda os resultados da pesquisa Regic, ao considerar uma das classes da Regic - a capital regional -, por outro, desconsidera a pertinência conceitual da condição de metrópole, assumida como centralidade principal na escala hierárquica, em toda a série desenvolvida e aprimorada pelo IBGE. Mais grave que esse equívoco de compreensão, cabe registrar que, entre as alteraçóes promovidas no Estatuto da Metrópole pela Lei Federal nํㅜ 13.688/2018, nesse mesmo art. 2º, houve a supressão do texto original, que então dispunha:

Parágrafo único. Os critérios para a delimitação da região de influência de uma capital regional, previstos no inciso $\mathrm{V}$ do caput deste artigo considerarão os bens e serviços fornecidos pela cidade à região, abrangendo produtos industriais, educação, saúde, serviços bancários, comércio, empregos e outros itens pertinentes, e serão disponibilizados pelo IBGE na rede mundial de computadores (Brasil, 2018, grifo nosso).

Talvez como compensação, a mesma lei inclui no art. $3^{\circ}$ do Estatuto da Metrópole: $\$ 2^{\circ}$ - A criação de uma regiáo metropolitana, de aglomeraçáo urbana ou de microrregiáo deve ser precedida de estudos técnicos e audiências públicas que envolvam todos os Municípios pertencentes à unidade territorial (Brasil, 2018). 


\subsection{0 papel da rede urbana no enfrentamento à pandemia}

O conhecimento da hierarquia urbana, das relaçóes entre centros e da abrangência de suas regiôes de influência é imprescindível à prestação de serviços essenciais, como saúde e educação, pois organizam sua oferta em sistemas que operam por meio dessas relaçóes. Os serviços de maior complexidade são oferecidos nas centralidades principais e devem garantir acesso a todos os municípios e povoados de sua regiáo de influência. Em regióes nas quais a rede urbana é mais densa e complexa, a população náo encontra dificuldade de acesso, mas onde a rede é menos densa e as distâncias entre centros são maiores ou se encontram mais obstáculos nos trajetos e meios de locomoção, a população pode correr risco de morte.

A pandemia do novo coronavírus, em curso, vem colocando em xeque as condiçóes de garantia das centralidades no atendimento por serviços de alta complexidade e na possibilidade de acesso ao atendimento por esses serviços em muitas áreas das regióes Norte e Centro-Oeste. Em abril de 2020, algumas informaçóes da Regic 2018, sobre o comportamento da rede de cidades na área de saúde, foram divulgadas antecipadamente (IBGE, 2020b). Quesitos do questionário da pesquisa investigaram o deslocamento de pessoas entre municípios na busca de acesso a serviços de saúde de baixa, média e alta complexidade. Os resultados poderiam contribuir para identificar as cidades polarizadoras desses serviços e as regiōes de atendimento, subsidiar a elaboração de políticas públicas sanitárias e a definição de medidas de contenção dos efeitos da disseminação da Covid-19, bem como seriam úteis também à elaboração de planos e da logística de atendimento nas cidades brasileiras.

As centralidades urbanas e sua hierarquia são determinadas pela concentração de bens e serviços especializados e pelo grau de complexidade que apresentam, razão pela qual os dados disponibilizados possuem a qualidade de estarem organizados e mapeados conforme os deslocamentos das cidades em busca de serviços de saúde de baixa, média e alta complexidade. A partir desta informação, torna-se possível tanto prever formas de ampliar e garantir a oferta dos serviços quanto de analisar e explicar o processo em curso. À época da disponibilização dos dados, Manaus passava por momento de alta saturação dos leitos de UTI, com taxas exponenciais de crescimento das mortes. Os resultados mapeados da pesquisa permitem que se entenda em grande parte a razáo da dificuldade do atendimento aos contaminados, dada a alta dependência de todos os municípios do Amazonas da infraestrutura hospitalar existente somente na capital (figura 1). Valendo-se desta lógica, medidas federais e regionais para o enfrentamento da pandemia poderiam ter sido tomadas, antecipando-se às possibilidades geradas de necessidade de leitos de UTI, em função do número de municípios dependentes dessa infraestrutura e da interiorização dos contágios da doença.

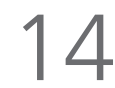


FIGURA 1

Deslocamentos para serviços de saúde de baixa, média e alta complexidades - Brasil (2018)

$1 \mathrm{~A}$ - Deslocamentos para serviços de saúde de baixa e média complexidades

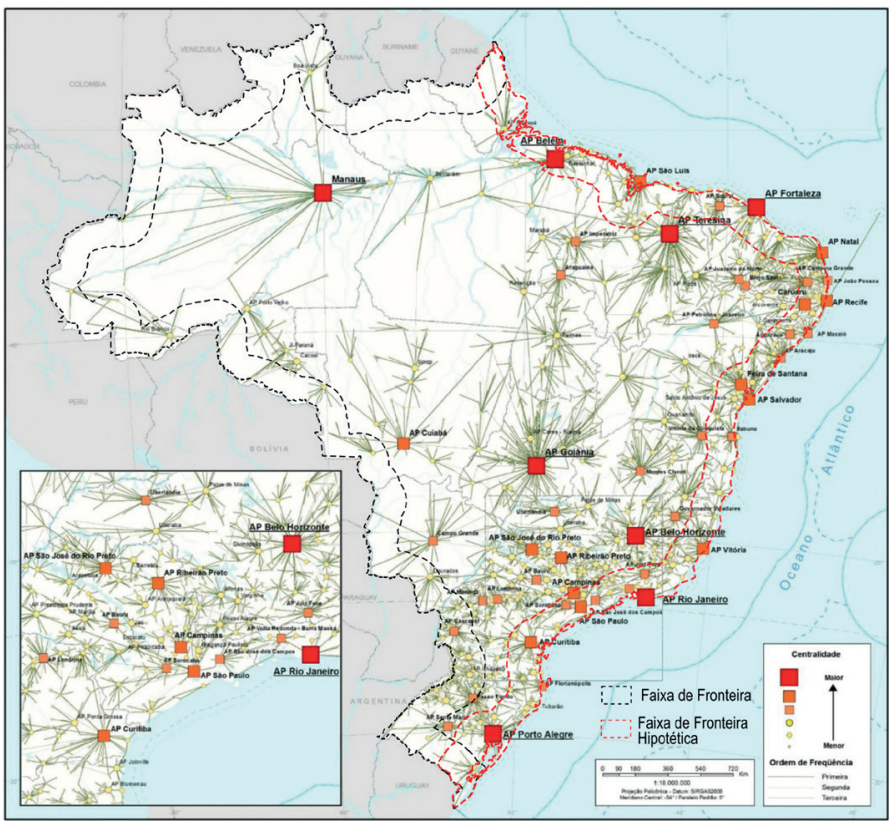

1B - Deslocamentos para serviços de saúde de alta complexidade

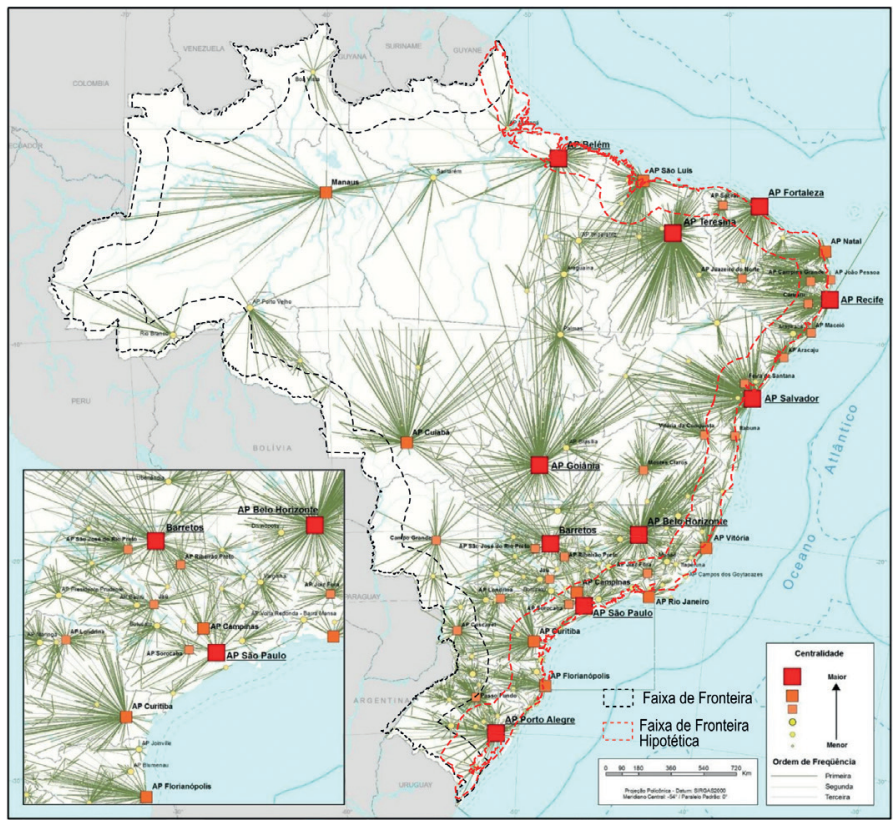

Fonte: IBGE (2020b, p. 10 e 13).

Elaboração: adaptada pela Equipe Fronteiras Ipea. 
Considerando o sentido das relações da centralidade para os municípios que compóem as regiôes de influência, os dados sugerem caminhos e direçôes potenciais de propagação da doença, tendo em conta que o vírus chegou às grandes metrópoles pelos aeroportos internacionais e se alastrou a partir destas centralidades de nível superior na hierarquia urbana. Embora a rede não seja determinada pela mobilidade física entre as cidades, os dados e as informaçóes de fluxos à procura de bens e serviços consistem em fortes indicativos da relação entre os centros, de tal forma que as medidas de controle à disseminação do vírus poderiam se valer da hierarquia de centralidades, das suas regiôes de influência e das distâncias entre as localidades para a montagem de estratégias de monitoramento dos casos, destinação de recursos humanos e materiais, e dotação de logística e infraestruturas.

Além disso, do ponto de vista estratégico, a classificação das cidades dos níveis superiores da hierarquia urbana aponta para polos que são, ao mesmo tempo, dotados de infraestruturas de alta complexidade, vitais para o enfrentamento da pandemia, mas constituídos em APs compostos por conjuntos de municípios em elevado grau de desigualdade econômica e social. Sáo arranjos espaciais de alta densidade, em cuja unidade, caracterizada por contradiçôes, concentra-se a oferta dos serviços mais qualificados e um elevado volume de demandas desatendidas até mesmo por serviços básicos. Contradiçôes que, nas palavras de Santos (2020), conforme se aprende com a cruel "pedagogia do vírus", representam um contexto do sofrimento humano de grupos sociais vulneráveis, para os quais está sendo mais difícil viver durante a pandemia. ${ }^{4}$

Em síntese, existem informaçóes que, se consideradas em políticas públicas, contribuem para transformar a hierarquia de cidades em uma rede articulada, capilarizada e dotada de condiçôes de oferta de bens e serviços urbanos que permitem seu usufruto com maior igualdade às pessoas e regióes do território. Desconsiderá-las, como no caso da pandemia, reforça-se a desigualdade social e, ao fazê-lo, evidencia-se a fragilidade e a incapacidade do Estado em dar resposta, principalmente, às ações emergenciais.

4. Compostos predominantemente por mulheres, trabalhadores precários e informais, trabalhadores de rua, populações em situação de rua, moradores de periferias pobres das cidades, pessoas com deficiência, idosos, migrantes e refugiados. Na análise, Santos (2020, p. 17) conclui: "ao contrário do que é veiculado pela mídia e pelas organizações internacionais, a quarentena não só torna mais visíveis, como reforça a injustiça, a discriminação, a exclusão social e o sofrimento injusto que elas provocam." 


\section{A TRAJETÓRIA DA LINHA DE PESQUISA NO IBGE}

Os estudos sobre a hierarquia urbana brasileira e as regióes de influência das cidades pelo IBGE descrevem uma trajetória longa, que se aprimora a cada nova pesquisa, e é cada vez mais respeitada e considerada nos meios acadêmicos, governamentais e empresariais. Nesta seção, se colocam em memória os objetivos e os procedimentos técnicos da pesquisa desenvolvida pelo IBGE, de 1966 a 2018, sobre a qual se descrevem os principais aprimoramentos metodológicos e operacionais (subseção 3.1), com destaque à adoção dos APs como unidades de pesquisa, e se analisa a comparabilidade das escalas de classificação dos centros na hierarquia urbana (subseção 3.2). Como forma de aferir a possibilidade comparativa entre os períodos considerados, na subseção 3.3, desenvolve-se uma análise do posicionamento da classe principal da hierarquia: a metrópole.

\subsection{Aprimoramentos metodológicos e operacionais}

Essa pesquisa pode ser considerada única, em conteúdo e continuidade, entre os países latino-americanos. Nas palavras do IBGE (2020a, p. 9):

A pesquisa Regióes de Influência das Cidades - Regic tem o propósito de identificar e analisar a rede urbana brasileira, estabelecendo a hierarquia dos centros urbanos e as regiōes de influência das Cidades. O estudo constitui uma abordagem fundamental para a compreensão da geografia do País, uma vez que estabelece critérios para a qualificação das Cidades e das relaçóes entre elas, revelando eixos de integração no território e padrôes diferenciados de distribuição de centralidades urbanas. Por dar visibilidade às centralidades e à dinâmica dos fluxos que as conectam, essa pesquisa constitui um instrumento importante para as decisóes locacionais e aplicaçóes práticas, tanto do planejamento estatal quanto da sociedade em geral.

Com tal finalidade e possibilidades, a pesquisa vem sendo desenvolvida por um período que supera cinco décadas, aprimorando-se para captar o comportamento da rede urbana como reflexo das dinâmicas econômicas e sociais, em transformação. Uma breve leitura da trajetória metodológica e operacional das pesquisas sobre regióes funcionais e as de influência das cidades, aqui nominadas singularmente por Regic, mostra os substanciais ajustes que se sucederam, sem que se rompesse o mesmo fio condutor teórico e conceitual e um mesmo formato de operacionalização, por meio de pesquisa direta, e complementarmente, dados secundários. Essa trajetória está registrada nas informaçóes sobre os "estudos anteriores", na publicação do estudo Regic 2007 (IBGE, 2008). 
A primeira pesquisa teve início em 1966, resultando em dois produtos: Divisão do Brasil em micro-regióes homogêneas (IBGE, 1970) e Divisão do Brasil em regioes funcionais urbanas (IBGE, 1972). Tomou por base a metodologia proposta por Michel Rochefort (Rochefort, 1961; ${ }^{5} 1965 ;{ }^{6}$ Rochefort e Hautreux, 1963), ${ }^{7}$ adotada para análise da rede urbana francesa, buscando identificar os centros polarizadores, dimensionar a área de influência desses centros e os fluxos que se estabeleciam. ${ }^{8} \mathrm{~A}$ análise se voltava à distribuição de bens (produtos industriais) e serviços (ligados ao capital; administração e direção; educação; saúde; e divulgação) de forma complementar. Para a pesquisa, foi elaborado um questionário ${ }^{9}$ que visava identificar onde a população local buscava bens e serviços não ofertados no município. Este foi respondido pelos agentes municipais de estatística do IBGE de todos os municípios com população superior a 10 mil habitantes (731 municípios). Compunha-se de 135 itens agrupados em: i) atividade agrícola e extrativa vegetal; ii) pecuária; iii) atividade comercial; e iv) saúde, educação, estabelecimentos bancários, transporte e comunicações. Como resultado dessa pesquisa, chegou-se a quatro níveis de centros urbanos com subdivisóes: nível 1 - 1a) grande metrópole nacional (São Paulo), 1b) metrópole nacional (Rio de Janeiro), 1c) centros metropolitanos regionais (Recife, Belo Horizonte, Salvador e Porto Alegre) e 1d) centros macrorregionais (Curitiba, Fortaleza, Belém e Goiânia); nível 2 - centros regionais; nível 3 - centros sub-regionais; e nível 4 - centros locais.

Na pesquisa de 1978 (IBGE, 1987), já se adotava a base conceitual que orientaria as subsequentes: a teoria das localidades centrais (Christaller, 1966), na qual a centralidade decorre do papel de distribuição de bens e serviços para a população.

Segundo essa teoria, a freqüência da demanda acarreta padróes de localização diferenciados: bens e serviços de consumo freqüente podem ser oferecidos por centros acessíveis a uma população próxima, e têm mercado mínimo e alcance espacial reduzidos. Os bens e serviços de uso mais

5. Rochefort, M. Método de estudo das redes urbanas (interesse da análise e do setor terciário na população ativa). Boletim Geográfico, Rio de Janeiro, IBGE, v. 19, n. 160, p. 3-18, 1961.

6. Rochefort, M. La armature urbaine et le réseau urbaine. Notions et problèmes méthodologiques d'analyse. Revista Geográfica, Rio de Janeiro, Instituto Pan-Americano de Geografia e História, n. 63, t. XXXV, p. 33-50, jul.-dez. 1965.

7. Rochefort, M.; Hautreux, J. La fonction régionale dans l'armature urbaine française. Paris: Ministère de la Construction et de l'Équipement, 1963.

8. Há que se sublinhar também a importância de dois trabalhos que contribuíram nessas reflexões iniciais, o estudo de Geiger (1963), que introduziu a discussão e pode ser considerado o pioneiro a se propor a interpretar as redes urbanas, abrangendo todo o país, e também o de Milton Santos, que se valeu do mesmo método de Rochefort para interpretar a rede urbana do recôncavo baiano (Santos, 1959).

9. Esse questionário pioneiro foi elaborado em colaboração com o Escritório de Pesquisa Econômica Aplicada, atual Ipea. 
raro, por sua vez, têm mercado mínimo e alcance espacial maiores, e tendem a localizar-se em um menor número de centros urbanos de hierarquia mais elevada (IBGE, 2008, p. 129).

Foram aplicados questionários em 1.416 municípios, considerados com capacidade de exercer centralidade além de seus limites municipais, ou que tinham sido definidos como centros locais na pesquisa anterior. O questionário apoiou-se em 76 funçôes centrais (bens e serviços), cuja concentração permitiu agrupar os municípios em seis conjuntos hierarquizados: i) metrópole regional (Belém, Belo Horizonte, Curitiba, Fortaleza, Goiânia, Manaus, Porto Alegre, Recife, Rio de Janeiro, Salvador e São Paulo); ii) centro submetropolitano; iii) capital regional; iv) centro sub-regional; v) centro de zona; e vi) município subordinado.

A pesquisa de 1993 (IBGE, 2000) fugiu bastante às anteriores e posteriores no que se refere à nomenclatura das classes de centros, porém manteve o alinhamento dos objetivos e procedimentos operacionais. Em relação aos estudos anteriores, a principal diferença é que nesses os centros foram identificados em dois momentos distintos: inicialmente, definida a centralidade e sua hierarquia, segundo seu equipamento; e posteriormente, com base nos fluxos, identificadas suas áreas de influência. $\mathrm{O}$ estudo de 1993 se difere por ser o único no qual o método adotado define a centralidade e a regiăo de influência em uma única etapa. Além disso, na pesquisa de 1993, a essência da investigação recaiu nas redes de relaçóes.

O estudo focava o papel das redes para viabilizar a circulação e a comunicação, fundamentais para a organização de um espaço onde os elementos fixos interagem pelo intercâmbio de fluxos. Ressaltava os diferentes níveis, intensidades e sentidos dos fluxos, sendo o espaço perpassado por redes desiguais e simultâneas, cujas ligaçóes são utilizadas de maneiras distintas pelos vários agentes sociais. A rede de lugares centrais seria, então, um dos possíveis desenhos das redes geográficas (IBGE, 2000, p. 130).

Foram investigadas 46 funções centrais, subdivididas em três grupos: i) baixa complexidade; ii) média a elevada complexidade; e iii) aquelas ligadas à procura por serviços de informação: sedes de jornais diários e de emissoras de rádios AM ou FM. O questionário foi respondido pela rede de agências do IBGE em 2.106 municípios selecionados pelo desempenho de atividades indicativas de centralidade extramunicipal, além dos municípios com população superior a 20 mil habitantes. Como informa o IBGE (2008, p. 130), as "cidades de São Paulo, Rio de Janeiro, Belo Horizonte, Porto 
Alegre, Curitiba, Salvador, Recife, Fortaleza e Brasília foram excluídas da pesquisa de informaçôes, e sua atuação foi inferida a partir das citações a elas feitas pelos municípios investigados". Foram definidos oito níveis de centralidade: máximo (Belo Horizonte, Curitiba, Fortaleza, Goiânia, Porto Alegre, Recife, Rio de Janeiro, Salvador e São Paulo); muito forte; forte; forte para médio; médio; médio para fraco; fraco; e muito fraco.

Nos estudos seguintes, retoma-se a concepção utilizada nos primeiros, com a classificação e hierarquização dos centros seguida pela definição de suas áreas de influência. $\mathrm{Na}$ pesquisa de 2007, a função de gestáo pública e empresarial do território passa a ser central nessas etapas, pois estabelece relaçóes de controle, decisão e comando entre centros urbanos, demarcando, os nós das redes hierárquicas que influenciam os demais centros. Do total de 5.567 municípios existentes em 2007, 1.082 foram identificados segundo o critério de gestão, sendo 906 centros de gestão federal e 724 de gestão empresarial, e desses, 711 foram definidos como centros de gestáo do território. Para os centros de gestão do território, as ligaçôes entre os centros foram estudadas com base em dados secundários; para os demais 4.625 municípios, foi realizada pesquisa direta, levantando informaçóes sobre uma ampla gama de relacionamentos. O questionário respondido pela rede de agências do IBGE contemplou as principais ligaçôes de transportes regulares, particularmente as que se dirigem aos centros de gestão do território, e os principais destinos dos moradores para obtenção de produtos e serviços (compras em geral, educação superior, aeroportos, serviços de saúde, bem como os fluxos para aquisição de insumos e o destino dos produtos agropecuários). O IBGE anota que:

Uma vez delimitadas as regiōes de influência, verificou-se que o conjunto de centros urbanos com maior centralidade - que constituem foco para outras cidades, conformando áreas de influências mais ou menos extensas - apresenta algumas divergências em relação ao conjunto dos centros de gestão do território. Neste último, há casos de atuação restrita ao próprio território, exercendo funções centrais apenas para a população local. Inversamente, há cidades não incluídas naquele conjunto cuja centralidade foi identificada a partir do efeito polarizador que exercem sobre outras (2008, p. 11).

A etapa final foi a hierarquia dos centros urbanos, que considerou a classificação dos centros de gestáo do território, a intensidade de relacionamentos e a dimensão da regiáo de influência de cada centro, bem como as diferenciaçóes regionais. Vale destacar 
que os municípios e as áreas de concentração de população (ACPs) ${ }^{10}$ foram as unidades territoriais que constituíram o universo do estudo de 2007. A classificaçáo dos centros se dá em: i) metrópoles: grande metrópole nacional (ACP de São Paulo), metrópoles nacionais (ACPs de Rio de Janeiro e Brasília) e metrópoles (ACPs de Belém, Belo Horizonte, Curitiba, Fortaleza, Goiânia, Manaus, Porto Alegre, Recife e Salvador); ii) capitais regionais $\mathrm{A}, \mathrm{B}$ e $\mathrm{C}$; iii) centros sub-regionais A e B; iv) centros de zona A e B; e v) centros locais.

A pesquisa de 2018 (IBGE, 2020a) repete essa mesma escala de centros e consolida como unidade territorial de pesquisa a "Cidade", que pode ser composta por um único município ou por um arranjo populacional. ${ }^{11}$ Como na pesquisa anterior, conta com a rede de agências do IBGE para aplicação de entrevistas em municípios, que investigam "o deslocamento dos habitantes no território em busca dos centros urbanos ofertantes de bens e serviços" (op. cit., p. 9). ${ }^{12}$ Os resultados dessa etapa se somam "com os dados secundários levantados sobre a hierarquia dos centros e as ligaçôes imateriais entre as Cidades" (op. cit., p. 9). Para a operacionalização dessa pesquisa, foram procedidos alguns aprimoramentos na metodologia, como "o uso de três informantes por Cidade; sistemas de crítica automatizados embutidos nos dispositivos móveis de coleta; perguntas tematicamente mais desagregadas no questionário aplicado; e maior quantidade de Municípios abrangidos pelos questionários" (IBGE, 2020a, p. 9). Valeu-se ainda de estudos temáticos precedentes, realizados ao longo do período entre a penúltima e esta última pesquisa, com ênfase ao de ligaçôes rodoviárias e hidroviárias entre centros (IBGE, 2017), assim como ajustes no

10. Conforme o IBGE (2008, p. 11), "as ACPs são definidas como grandes manchas urbanas de ocupação contínua, caracterizadas pelo tamanho e densidade da população, pelo grau de urbanização e pela coesão interna da área, dada pelos deslocamentos da população para trabalho ou estudo. As ACPs se desenvolvem ao redor de um ou mais núcleos urbanos, em caso de centros conurbados, assumindo o nome do município da capital, ou do município de maior população".

11. Anota-se importante observação da geógrafa Olga Firkowski, em disciplina ofertada em 2 de outubro de 2020 no curso As metrópoles e a ordem urbana brasileira: os desafios do direito à cidade, realizado pelo Observatório das Metrópoles, de que em todo o volume da Regic, essa concepção de cidade que representa a "priorização da unidade funcional urbana, por vezes composta por várias áreas urbanas de diferentes municípios" passa a ser grafada com "C" maiúsculo, destacando sua importância e distinguindo-a de outras concepções de cidade.

12. Segundo o IBGE (2020a, p. 72) "O agente de pesquisa do IBGE realizou a entrevista com pessoas atuantes em três instituições, sendo a primeira necessariamente a prefeitura municipal. As demais instituições, que poderiam ou não existir no município em questão, foram visitadas na seguinte ordem: 2a agência dos Correios; 3a cartório; 4a fórum municipal; 5a agência bancária; 6a delegacia de polícia; 7a igreja/instituição religiosa; 8a associações de lojistas; e/ou 9a rádios locais. A ordem estabelecida deveria ser seguida, de modo que só foi buscado outro informante quando o anterior na lista não estava disponível no município. Deve-se destacar que os informantes não forneceram respostas oficiais em nome das instituições, mas com base em suas próprias vivências e percepções, visto que a pesquisa buscou o conhecimento tácito disseminado na localidade". 
tratamento dos dados de gestão (IBGE, 2014) e na definição das unidades espaciais que transcendem o município (IBGE, 2016). Ademais, além de dar continuidade à ênfase na gestão do território, agregou em sua análise a qualificação das centralidades em função das relaçóes de longa distância, ou aquelas para além das hinterlândias (regióes de influência), caracterizadas pela inexistência das barreiras espaciais clássicas como fronteiras, divisas ou relevos. Estendem-se, dessa forma, funçôes do Estado e do mercado, a partir das quais estas relaçóes ou o seu nível de city-ness $^{13}$ poderiam ser captados. Também inovou em qualificar os municípios da faixa de fronteira terrestre brasileira com pesquisa inédita sobre as ligaçóes internacionais entre cidades para acesso a bens e serviços.

Por seguirem uma mesma linha teórica de construção, uma análise comparada torna-se possível, por meio dos dados disponibilizados, facilitada com base nos mapas resultantes de cada um dos cinco estudos. Essas informaçóes constituem uma série histórica que representa fonte expressiva para a leitura das transformaçóes no território brasileiro. Contudo, para que tal leitura possa ser realizada de forma mais apropriada, é importante ressaltar alguns ajustes entre os estudos nessa sequência de aprimoramentos da pesquisa, de forma a se compreender especificidades inerentes a cada um dos desenhos de centralidades e regióes de influência conforme segue.

1) Enquanto na primeira pesquisa, de 1966 (IBGE, 1972), as centralidades e suas regióes de influência foram obtidas por funçóes de bens e serviços ofertados de uma forma genérica, a partir da pesquisa de 1978 (IBGE, 1987), com base em Christaller (IBGE, 2008), os estudos passaram a considerar a importância dos serviços raros, sendo que as funçóes para a definição da rede foram subdivididas em baixa, média e elevada complexidades.

2) As pesquisas que sucedem a essas estabeleceram gradualmente critérios cada vez mais consistentes para a definição dos municípios posicionados no mais alto nível na hierarquia urbana.

3) A pesquisa de 1993 (IBGE, 2000) é peculiar em relação às demais em função do foco adotado sobre o papel das redes para viabilizar a circulação e a comunicação,

13. 0 IBGE (2020a) incorpora de Taylor (2001) e Taylor, Hoyler e Verbruggen (2010) a compreensão de que a posição de uma cidade em uma rede urbana se define a partir a partir dos fluxos de relações que estabelecem com outras cidades, distinguindo o resultado dessas relações externas nos conceitos de town-ness e city-ness. 0 primeiro é atribuído ao espaço urbano das cidades pequenas como produto de suas relações locais com a hinterlândia, dependentes da contiguidade e da fricção da distância, pela prestação de serviços locais. 0 segundo, a cidades maiores, cuja economia passa a ser regida por relações externas, por conexões a longa distância, que não levam obrigatoriamente a relações hierárquicas, mas reticulares, para além das hinterlândias. Para mais informações, ver IBGE (2020a, p. 70). 
incluindo funções de busca de bens e serviços de informações (sedes de jornais diários e empresas de rádio AM e FM).

4) Na pesquisa de 2007 (IBGE, 2008), destaca-se o papel que a gestão do território obteve na definição da rede, a partir da inclusão de um grande número de funçóes de busca dos serviços por órgãos do Estado e empresas privadas e, além disso, uma série de outras funções, como internet, ensino superior, rede de televisão aberta, para maior qualificação das centralidades.

5) Em 2018 (IBGE, 2020a), a classificação das centralidades considerou as conexôes de longa distância pela presença de empresas de atuação internacional e as ligaçóes entre cidades da faixa de fronteira terrestre brasileira e dos países da América do Sul para acesso a bens e serviços.

6) Entre as pesquisas, há diferentes critérios utilizados para a definição do número de cidades a serem pesquisadas, partindo de municípios com população superior a 10 mil habitantes, na primeira pesquisa, até alcançar a totalidade na de 2018.

7) $\mathrm{O}$ entendimento de cidade, que a partir da pesquisa de 2007 incorpora unidades territoriais formadas por conjuntos de municípios como centralidades nas redes urbanas, ou seja, as áreas de concentração de população nessa pesquisa e, na última, os APs.

8) Ainda, a classificação hierárquica, que recebeu diferentes nominaçôes ao longo da série (no item 4 é realizada a equivalência e análise das várias escalas utilizadas).

As contribuições dessas pesquisas sustentam compreensões que perpassam toda a série, algumas se mantendo inalteradas, outras ajustadas a partir de estudos realizados, outras ainda incorporadas ao longo do período, merecendo ser salientadas conforme a seguir.

1) APs: juntamente com municípios que compóem a unidade urbana de análise e exposição dos resultados da pesquisa. São "unidades territoriais compostas por mais de um Município, que apresentam integração significativa em razão da contiguidade das áreas urbanizadas ou da presença de deslocamentos frequentes dos habitantes para trabalhar ou estudar" (IBGE, 2020a, p. 72). Por serem indissociáveis como unidade urbana e forte a integração de movimento pendular para estudo e/ou trabalho, "justifica considerá-los como um único nó da rede urbana” (op. cit., p. 11).

2) Gestão do território: refere-se ao "papel das Cidades na articulação territorial da gestão empresarial, bem como sua centralidade nessa função"14 (IBGE, 2020a, p. 74).

14. Foram identificadas a partir de dados de 2016, do Cadastro Central de Empresas (Cempre), organizado pelo IBGE. 
Define-se pela composição e relação entre os resultados da gestão empresarial e da gestão pública, ou seja, pela “intersecção dos 1.896 centros de gestão pública e dos 1.288 centros de gestão empresarial, emergiram 1.117 centros de gestão do território, que assim se caracterizavam por serem considerados como centros de relativa importância nos dois âmbitos de gestão" (op. cit., p. 75). Assim, "as Cidades brasileiras foram classificadas, hierarquicamente, a partir das funçóes de gestão que exercem sobre outras cidades, considerando tanto seu papel de comando em atividades empresariais quanto de gestão pública, e, ainda, em função da sua atratividade para suprir bens e serviços para outras cidades" (op. cit., p. 11).

3) Região de influência das cidades: o "alcance desse comando e atratividade no território corresponde à delimitação de sua área de influência, ou seja, quais Cidades estão subordinadas a cada centralidade classificada na pesquisa" (IBGE, 2020a, p. 11). Essa regiāo se configura a partir dos vínculos entre centros urbanos de menor hierarquia $\mathrm{e}$ àqueles com hierarquia superior; possui uma feição espacial reticular, constituída pelo conjunto de unidades urbanas que realizam ligações entre si; "não necessariamente contígua, e, dependendo da escala, com superposiçóes e duplas subordinaçóes de cidades" (op. cit., p. 72).

4) Relaçóes urbanas de proximidade e de longa distância. As primeiras foram obtidas nos resultados de questionário, cujo módulo principal foi aplicado em $5.503 \mathrm{mu}$ nicípios brasileiros, "excluindo-se aqueles que apresentam alto nível de centralidade de gestão do território, por serem Municípios que tendem a suprir satisfatoriamente os bens e serviços à população que neles habita” (IBGE, 2020a, p. 72). Os temas pesquisados foram: compras de vestuário e calçados; móveis e eletroeletrônicos; serviços de saúde de baixa, média e alta complexidades; ensino superior; atividades culturais e esportivas; uso de aeroporto; e a origem dos jornais que circulam no município; além dos resultados da pesquisa sobre ligaçôes rodoviárias e hidroviárias entre centros (IBGE, 2017). O percentual indicado nos questionários serviu de base para o índice de atração para cada cidade, utilizado nos ajustes de classificação da hierarquia urbana. "O conjunto de resultados do questionário traduz as relaçôes de proximidade da rede urbana, o componente de town-ness, a ser integrado com as relaçôes de longa distância e o componente de city-ness, para compor a rede urbana final”. As relaçóes urbanas de longa distância foram geradas pelas informaçóes de comando e gestão pública e empresarial do território.

\subsection{Arranjos populacionais como unidades de pesquisa}

Em estudo do IBGE são identificadas duas categorias entre os municípios brasileiros: concentraçôes urbanas e APs. A primeira "refere-se a unidades urbanas que impelem ao movimento um volume cada vez maior de pessoas, que veem, nos médios e grandes 
centros, oportunidades de trabalho e estudo, compatíveis com os novos padrôes econômicos do capitalismo contemporâneo" (IBGE, 2016, p. 19). A segunda, orientada pela "noção de integração, medida pelos movimentos pendulares para trabalho e estudo ou a contiguidade urbana, que assim sintetizam os vários processos envolvidos” (...), resulta, em muitos casos, do "transbordamento de elementos estruturadores das grandes concentrações urbanas" (op. cit., p. 19), e se relaciona às tendências de concentração metropolitana "com base na chamada economia de aglomeração e desconcentração de atividades produtivas para as cidades de menor porte" (op. cit., p. 14).

Essas categorias podem se sobrepor entre si. Tanto as grandes concentraçôes urbanas (unidades com população superior a 750 mil habitantes) como parte das médias concentraçóes (entre 100 mil e 750 mil habitantes) compóem-se majoritariamente de municípios em APs, o que evidencia esse como um padrão predominante de configuração espacial urbana no Brasil contemporâneo. Motivo pelo qual o IBGE, para a classificação da hierarquia dos centros na pesquisa Regic de 2018, assume como uma centralidade una o conjunto formado por municípios e por APs.

Isto se deve ao fato de que a unidade funcional Cidade, objeto do atual estudo, pode vir a ser composta não apenas por um, mas por vários Municípios que são indissociáveis como unidade urbana. Trata-se de Municípios conurbados ou que possuem forte movimento pendular para estudo e trabalho, com tamanha integração que justifica considerá-los como um único nó da rede urbana (IBGE, 2020a, p. 11).

Informações atualizadas e disponibilizadas em relação anexa à publicação da Regic 2018 registram 289 APs, formados por 960 municípios (mapa 1), que abrigam mais de metade da população residente no Brasil - no estudo original (IBGE, 2016) eram 294 APs compostos por 955 municípios. Alguns possuem população inferior a 100 mil habitantes; outros são fronteiriços, em ocupaçôes contínuas com municípios dos países vizinhos. Entre os APs, 90\% conjugam até cinco municípios, o que sugere "que o processo de aglomeração está se intensificando em centros de menor porte populacional nos últimos anos, devido ao aumento da mobilidade” (IBGE, 2016, p. 19). No entanto, os demais $10 \%$ de APs incorporam as principais hierarquias da rede urbana, particularmente as metrópoles. A única metrópole que não configura AP é Manaus, com 2,2 milhões de habitantes em 2019, considerada, assim, uma grande concentração urbana. 
MAPA 1

Concentrações urbanas e arranjos populacionais - Brasil (2018)

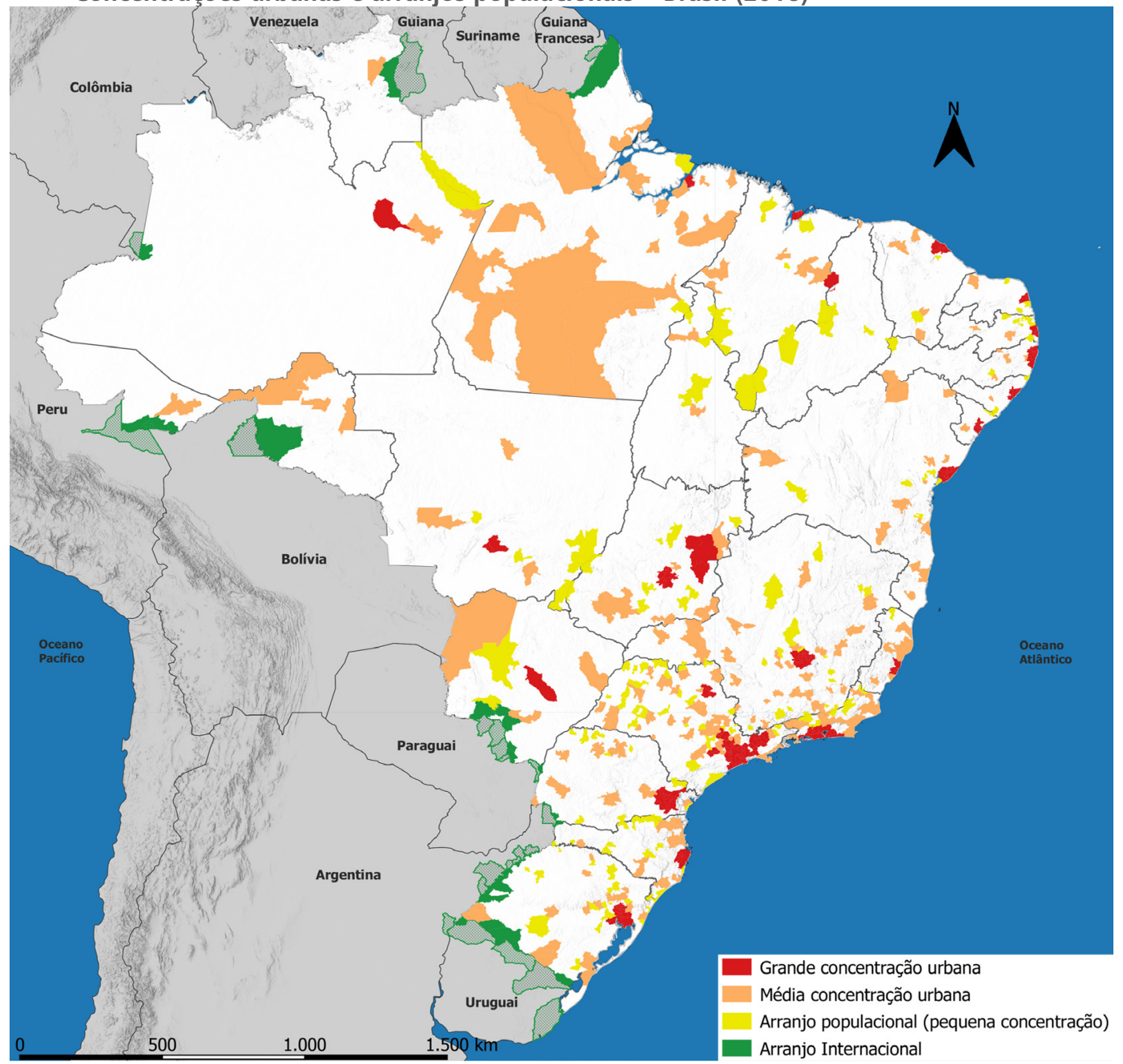

Fonte: IBGE (2020a)

Elaboração: Equipe Fronteiras Ipea.

Obs.: 1. No caso dos APs internacionais, foram mapeados os municípios contíguos dos países vizinhos, com os quais compõem arranjos transfronteiriços (Moura e Oliveira, 2018).

O que muda nos APs de sua identificação original para a mais recente? As mudanças constatadas na comparação entre as bases de dados de 2016 e 2018 são: i) incorporação de pequenas APs em grandes concentrações urbanas, casos de: Porto Alegre, que incorpora os APs (com todos os municípios) de Ivoti, Novo Hamburgo-São Leopoldo, e Sapiranga; Presidente Prudente, que incorpora o AP de Pirapozinho (com mais um município); São José dos Campos, que incorpora o AP Taubaté-Pindamonhangaba (com todos os municípios); ii) inclusão de novos municípios, casos de: Porto Alegre, que agrega seis 
municípios (Capela de Santana, Dois Irmãos, Morro Reuter, Picada Café, São José do Hortêncio e São Sebastião do Caí); Presidente Prudente, que agrega dois municípios (Estrela do Norte e Tarabai); e iii) exclusão de municípios, casos de: Nova Uniáo, que pertencia ao AP de Belo Horizonte (MG); Itaverava, que pertencia ao AP de Conselheiro Lafaiete (MG); Cuitegi, que pertencia ao AP de Guarabira (PB).

Apesar dessas mudanças, a base de dados anexa ao estudo Regic 2018 náo traz as alteraçóes entre concentraçóes urbanas não formadas por APs, tampouco diferencia quais destes são considerados grandes ou médias concentrações. Há médias concentrações com pouco mais de 100 mil habitantes, e APs singulares com muito mais que isso, bem como grandes concentraçôes urbanas com pouco mais de 750 mil e médias com mais de 800 mil, seja pelo crescimento populacional no período seja por incorporação de novos municípios. Num exercício voltado a esta leitura da Regic 2018, considerando os critérios de corte de população estipulados no estudo original (IBGE, 2016), com base na população estimada pelo IBGE para 2019 (IBGE, 2019) e na relação atual dos APs, foram reclassificados municípios e APs, estes a partir da soma da população do conjunto que o compóe. Algumas alteraçóes tornaram-se evidentes: i) médias concentraçóes urbanas dos APs de Ribeirão Preto e Jundiaí (ambos em São Paulo) possuem população superior ao patamar de corte para grandes concentraçóes urbanas; ii) contrariamente, os APs internacionais Sant'Ana do Livramento (RS) e Ponta Porã (MS) não atingem o patamar populacional para média concentração urbana, salvo se forem acrescidos os municípios do país vizinho com os quais conformam um arranjo transfronteiriço (Rivera-Uruguai e Pedro Juan Caballero-Paraguai, respectivamente); iii) oito APs alcançam o patamar classificatório para média concentração, sendo eles: Laranjal do Jari (AP)/Almeirim (PA), Itumbiara (GO), Araxá (MG), Itaúna (MG), Votuporanga (SP), Leme (SP), Itapema (SC) e Nova Serrana (MG); e iv) 23 municípios, sendo dez na região Norte, quatro na Nordeste, seis na Sudeste, um na Sul e dois na Centro-Oeste, atingiram o patamar de média concentração urbana.

\subsection{Comparabilidade das escalas de classificação}

A abordagem sobre a trajetória das cinco pesquisas mencionadas mostra que, apesar dos ajustes metodológicos e operacionais e das mudanças substanciais nas nomenclaturas das classes, os resultados garantem um elevado grau de comparabilidade. No que toca à hierarquia urbana, observa-se que guardam muita proximidade quanto à classificação dos centros (quadro 1). 
QUADRO 1

Correspondência entre categorias de centros das pesquisas Regic

\begin{tabular}{|l|c|c|c|c|}
\hline Regic 1966 & Regic 1978 & Regic 1993 & Regic 2007 & Regic 2018 \\
\hline Grande metrópole nacional & Metrópole regional & Máximo & $\begin{array}{c}\text { Grande metrópole } \\
\text { nacional }\end{array}$ & $\begin{array}{c}\text { Grande metrópole } \\
\text { nacional }\end{array}$ \\
\hline Metrópole nacional & - & - & Metrópole nacional & Metrópole nacional \\
\hline Centro metropolitano regional & - & - & Metrópole & Metrópole \\
\hline Centro macrorregional & - & - & - & - \\
\hline Centro regional A & Centro submetropolitano & Muito forte & Capital regional A & Capital regional A \\
\hline Centro regional B & Capital regional & Forte & Capital regional B & Capital regional B \\
\hline- & - & - & Capital regional C & Capital regional C \\
\hline Centro sub-regional A & Centro sub-regional & Forte para médio & Centro sub-regional A & Centro sub-regional A \\
\hline Centro sub-regional B & - & Médio & Centro sub-regional B & Centro sub-regional B \\
\hline Centro local A & Centro de zona & Médio para fraco & Centro de zona A & Centro de zona A \\
\hline Centro local B & Município subordinado & Fraco & Centro de zona B & Centro de zona B \\
\hline- & - & - & Centro local & Centro local \\
\hline
\end{tabular}

Fontes: IBGE (2008; 2020a) e I pardes (2009).

Elaboração: Equipe Fronteiras Ipea.

No nível superior da hierarquia de centros, no qual se inserem as metrópoles, em três dos cinco períodos analisados, esteve presente a grande metrópole nacional, sucedida por metrópoles nacionais e algumas tentativas de se distinguir ainda dois tipos entre o conjunto metropolitano de 1966: centros metropolitanos regionais e centros macrorregionais. As hierarquias de 1978 e 1993 reuniram todas as subdivisóes anteriores, respectivamente nas classes de metrópoles regionais ou no nível máximo de centralidade. No nível subsequente, centros regionais ou submetropolitanos dos períodos iniciais tornaram-se capitais regionais nos dois últimos - centralidades de níveis muito forte e forte em 1993. O nível correspondente aos centros sub-regionais não mudou a nomenclatura ao longo dos períodos e reuniu as centralidades de níveis forte para médio e médio em 1993. Os centros locais de 1966 distinguiram-se entre centros de zona e municípios subordinados, em 1978, e centralidades de níveis médio para fraco e fraco, em 1993, mantendo-se como centros de zona nas últimas pesquisas. Em 2007, reapareceram os centros locais na base da hierarquia urbana, mantendo-se na de 2018, como um nível que agrega municípios que "exercem influência restrita aos seus próprios limites territoriais, podendo atrair alguma população moradora de outras Cidades para temas específicos, mas não sendo destino principal de nenhuma outra Cidade" (IBGE, 2020a, p. 13). É necessário sublinhar que em todos os períodos houve um conjunto de municípios, por diversas razões, não classificados. 
Como exemplo da possibilidade comparativa e da evolução histórica dos posicionamentos e reposicionamentos dos centros brasileiros na escala hierárquica, tomando por base exercício realizado por Ipardes (2009) em relação aos resultados da pesquisa de 2007, constrói-se um quadro específico para o nível superior da hierarquia urbana ao longo do período, no qual se destaca a inserção das metrópoles (quadro 2). Como observado por Ipardes (2009, p. 11), o quadro

permite concluir que a rede urbana brasileira, em seus centros principais, pouco se alterou nas últimas décadas. São Paulo se destaca como a principal metrópole nas pesquisas de 1966 e 2007, que escalonaram diferenciaçóes no nível metropolitano; enquanto as pesquisas de 1978 e 1993 agruparam as metrópoles em conjuntos únicos.

QUADRO 2

Centros posicionados no nível superior da hierarquia urbana das pesquisas Regic - Brasil

\begin{tabular}{|c|c|c|c|c|}
\hline Regic 1966 & Regic 1978 & Regic 1993 & Regic 2007 & Regic 2018 \\
\hline Grande metrópole nacional & Metrópole regional & Nível máximo & $\begin{array}{c}\text { Grande metrópole } \\
\text { nacional }\end{array}$ & $\begin{array}{c}\text { Grande metrópole } \\
\text { nacional }\end{array}$ \\
\hline São Paulo & São Paulo & São Paulo & São Paulo & São Paulo \\
\hline Metrópole nacional & - & - & Metrópole nacional & Metrópole nacional \\
\hline Rio de Janeiro & Rio de Janeiro & Rio de Janeiro & Rio de Janeiro & Rio de Janeiro \\
\hline - & - & - & Brasilia & Brasília \\
\hline Centro metropolitano regional & - & - & Metrópole & Metrópole \\
\hline Recife & Recife & Recife & Recife & Recife \\
\hline Belo Horizonte & Belo Horizonte & Belo Horizonte & Belo Horizonte & Belo Horizonte \\
\hline Salvador & Salvador & Salvador & Salvador & Salvador \\
\hline Porto Alegre & Porto Alegre & Porto Alegre & Porto Alegre & Porto Alegre \\
\hline - & Manaus & & Manaus & Manaus \\
\hline Centro macrorregional & - & - & - & - \\
\hline Curitiba & Curitiba & Curitiba & Curitiba & Curitiba \\
\hline Fortaleza & Fortaleza & Fortaleza & Fortaleza & Fortaleza \\
\hline Goiânia & Goiânia & Goiânia & Goiânia & Goiânia \\
\hline Belém & Belém & - & Belém & Belém \\
\hline- & - & - & - & Florianópolis \\
\hline- & - & - & - & Vitória \\
\hline - & - & - & - & Campinas \\
\hline
\end{tabular}

Fontes: IBGE (2008; 2020a) e Ipardes (2009).

Elaboração: Equipe Fronteiras Ipea. 
Algumas observaçóes cabem em relação a essa composição: i) que a rede e a hierarquia dos centros estão em constante transformação, permitindo reposicionamentos escalares e inserção ou até exclusão de novas centralidades entre as existentes; ii) que as metrópoles do Norte do Brasil, pelas especificidades das regióes nas quais se inserem, ofereceram algumas dificuldades na classificação nos períodos iniciais, superadas nas últimas pesquisas; e iii) que cada vez mais se evidencia que a formação dos APs, compondo uma unidade urbana, coloca em xeque o município, como unidade de pesquisa e análise, em se tratando de compreender o urbano contemporâneo, como também de gestão, no caso de políticas públicas que se voltam às funçôes de interesse comum, peculiares a essas configuraçôes espaciais.

São Paulo manteve-se no topo da hierarquia da rede urbana brasileira em todos os cinco períodos da pesquisa, tendo sido alterada apenas a denominação da classe em dois dos períodos do estudo, classificando-se como a grande metrópole nacional nos outros três. Rio de Janeiro oscilou entre a primeira e a segunda maior hierarquia, e nesta posição manteve-se como metrópole nacional nos mesmos três períodos, tendo Brasília se elevado à mesma categoria e se mantido a partir de 2007. Essas três metrópoles apenas se juntaram a outras em 1978, formando um conjunto de onze metrópoles regionais, e em 1993, também em um conjunto de nove centralidades com nível máximo. Nesses dois períodos, os conjuntos metropolitanos repetem as mesmas unidades, exceto em relação às duas metrópoles do Norte, Manaus e Belém, que não se enquadraram entre as centralidades de nível máximo em 1993. Nas demais pesquisas, esse conjunto foi categorizado com subdivisóes em 1966 (centros metropolitanos regionais e centros macrorregionais, também sem a inclusão de Manaus) e depois unido à categoria metrópole nas duas últimas pesquisas.

Assim, Belém, Belo Horizonte, Curitiba, Fortaleza, Goiânia, Manaus, Porto Alegre, Recife e Salvador mantiveram-se ao longo de todos os períodos, exceto em 1993, na condição de metrópoles, posicionadas em nível subsequente às integrantes nas categorias do topo da hierarquia - São Paulo, Rio de Janeiro e Brasília. Da mesma forma que Brasília se inseriu entre as metrópoles apenas em 2007, na pesquisa de 2018, os resultados da classificação trouxeram para esse nível Florianópolis, Vitória e Campinas - esta, a única entre as metrópoles que não se constitui capital de Unidade da Federação (UF). Exceto Manaus, todas essas metrópoles se constituem em APs, formados por um conjunto de 
municípios, e esse conjunto, enquanto uma unidade, sustenta a atratividade de cada um desses centros metropolitanos.

A disposição das centralidades metropolitanas na rede urbana brasileira, com poucas inserçóes de novas cidades ao conjunto, começa a se consolidar na primeira metade do século passado. Estudo realizado por Santos (1967) mostra que a evolução das posiçôes relativas às maiores cidades do Brasil, desde 1872 - ano em que ocorreu o primeiro recenseamento no país, pouco se alterou. Nesse ano, apenas Rio de Janeiro, Salvador e Recife tinham mais de 100 mil habitantes, enquanto São Paulo, na décima posição, tinha pouco mais de 30 mil. Em 1920, São Paulo, que já assume o posto de maior economia do país, alcança a segunda posição, precedida por Rio de Janeiro e sucedida por Salvador, Recife, Belém e Porto Alegre, entre as cinco mais populosas do país. A análise registra que até 1930, ocorria uma urbanização herdada do processo de colonização, comandado pelas cidades litorâneas, diretamente servis ao perfil de uma economia dependente, cujas produção e comercialização voltavam-se para o estrangeiro. Ademais, limitaçóes em transportes e comunicaçóes dificultavam a conformação de uma rede urbana, assim como a consolidação de uma metrópole nacional.

Em 1940, ainda se mantinham as mesmas cidades entre as cinco mais populosas, com pequenas alteraçóes na ordem da escala, mantendo-se Rio de Janeiro como a maior cidade brasileira. Com o desenvolvimento industrial, introdução de novos meios de transportes, redução na dependência do estrangeiro e formação de um mercado interno, transformações passam a ocorrer diferentemente em cada região, com resultados que dependem, ao mesmo tempo, "das condiçôes históricas e das possibilidades de mudanças que se criaram" (Santos, 1967, p. 82). Após 1940, dá-se um aumento da população das aglomeraçóes da região industrial, e uma redução da participação de cidades situadas fora dela, particularmente do Norte e do Nordeste, e já se faz prenunciar o estabelecimento de uma "rede brasileira de cidades, com uma hierarquia nacional" (op. cit., p. 82).

Em 1960, Santos (1967, p. 80) constata que o recenseamento "marca uma verdadeira reviravolta, São Paulo ultrapassa o Rio de Janeiro e torna-se a maior cidade brasileira. Recife é a terceira cidade do país, seguida de Belo Horizonte e Salvador. Esta agora ocupa o quinto lugar, seguida de perto por Porto Alegre; Fortaleza mantém seu sétimo lugar, enquanto Belém, Curitiba e Niterói vêm a seguir”. 
Esse autor pondera que o Rio de Janeiro foi "largamente e longamente beneficiado com a sua função política” (Santos, 1967, p. 85), tornando-se assim uma metrópole política e econômica. Com o desenvolvimento industrial de São Paulo, emerge uma nova metrópole econômica, capaz de criar um parque industrial e se equipar para abastecer o mercado que cresce com a população brasileira, favorecida pelo sistema rodoviário e pela indústria automobilística. Refere-se, também, que esse sistema beneficiou Brasília, construída para cumprir um papel político, e mais uma vez favoreceu São Paulo, aumentando ainda mais sua hegemonia e dando impulso à "urbanização interior”. "Desta forma, as antigas metrópoles continuaram a comandar o espaço, por intermédio de sua força política e de seu desempenho no escoamento dos produtos. O vínculo regional está preservado, porque, entre outras razões, as relações com São Paulo são sobretudo interurbanas" (op. cit., p. 86).

Sobre as classes dos centros, Santos (1967) evoca estudo de Geiger (1963), que propunha uma hierarquia urbana na escala de: metrópoles nacionais, metrópoles regionais, capitais regionais, centros regionais de primeira ordem, centros regionais de segunda ordem. Mas, preferia distinguir simplesmente metrópoles (grau de complexidade e funçôes que lhes asseguram domínio sobre e dependência das demais cidades), metrópoles incompletas (dominam extensões regionais do território, pois a organização dos transportes e a produção industrial são insuficientes às necessidades da população, portanto, incompletas) e centros regionais (relaçóes mais diretas e conforme as especificidades das diferentes regiōes de influência), estes comportando as capitais regionais (entendidas como as cidades-capitais estaduais, cuja função político-administrativa lhes garante certa capacidade de organização regional). ${ }^{15}$

Compreendidos os detalhes metodológicos e operacionais da pesquisa ao longo de cinco aplicaçôes, seus aprimoramentos, inserção de maior número de municípios pesquisados, e aferida a possibilidade comparativa entre as classes de centro, tendo em conta a evolução do posicionamento das metrópoles na escala da rede urbana, conclui-se pela qualidade dos resultados das pesquisas realizadas e pela possibilidade que auferem para a análise da rede urbana brasileira e de suas transformaçóes.

15. Sobre essa classificação, ver em Santos (1967, p. 86-90) a parte III, Os graus da hierarquia atual, do referido artigo. 


\section{COMPORTAMENTO DA REDE DE CIDADES}

Considerando os resultados das pesquisas realizadas sobre a hierarquia das cidades na rede urbana e as suas regióes de influência, nesta seção, se observará a rede em si: sua organização, suas transformações ao longo do período em análise, mudanças, permanências (subseção 4.1), e a variação nos níveis de centralidade (subseção 4.2). Neste caso, tratará da distribuição territorial dessas mudanças e permanências. Dada a ampla inserção de municípios pesquisados e a agregação de muitos em APs, a partir da pesquisa de 2007, serão salientados detalhes sobre a variação entre os dois últimos períodos da pesquisa.

\subsection{Mudanças e permanências na organização da rede}

Revisitar a interpretação da evolução da rede urbana brasileira e da hierarquia de centros que garantiram sua estrutura nos anos 1960, como se fez na subseção 2.3, mostrou que nessa época estava configurado, quase na íntegra, o primeiro nível de centralidades que vem se mantendo no topo da hierarquia urbana brasileira desde então, com algumas poucas, mas relevantes inserçóes - Brasília, Manaus, além das três mais novas metrópoles, Florianópolis, Vitória e Campinas. Da mesma forma, a rede sofre poucas transformações, a considerar o período entre as quatro pesquisas realizadas, como confirma o IBGE (2008):

verifica-se que a rede urbana apresenta notável estabilidade, principalmente no que se refere aos níveis hierárquicos mais altos, que, de modo geral, mantêm-se os mesmos. As principais alteraçóes evidenciadas acompanham o processo de ocupação do território no período, e as mudanças são mais frequentes nos níveis de hierarquia intermediária e baixa (p. 17).

Também se aponta, nesse período, a emergência de centros predominantemente nos estados de Mato Grosso, Rondônia e Tocantins, oeste do Amazonas e sul do Pará, e com menor intensidade, a ascensão de novos centros no Maranhão e Piauí. Nas áreas de ocupação mais antiga, "o quadro é mais estável, e algumas cidades deixam de exercer maior centralidade, num processo possivelmente ligado às mudanças nas redes de comunicação e transportes" (IBGE, 2008, p. 17).

Um olhar comparado sobre o desenho das redes urbanas e das regióes de influência dos centros nessas quatro pesquisas (figura 2) constata a extensão temporal da 
permanência das centralidades principais, os momentos das mudanças na distribuição das demais centralidades no território, o adensamento de algumas redes regionais e a própria formação de redes sub-regionais.

FIGURA 2

Rede urbana - Brasil
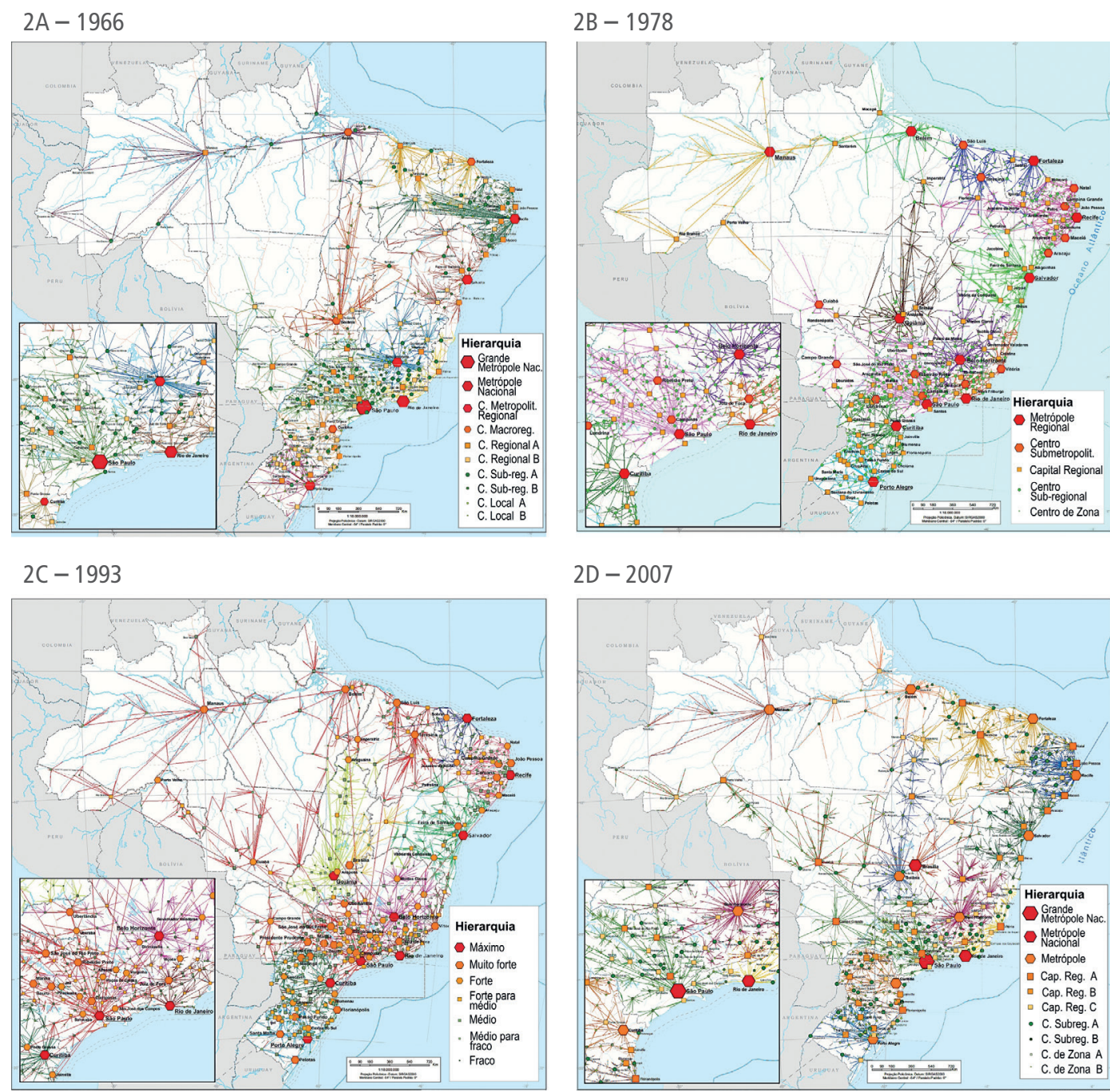

$2 D-2007$

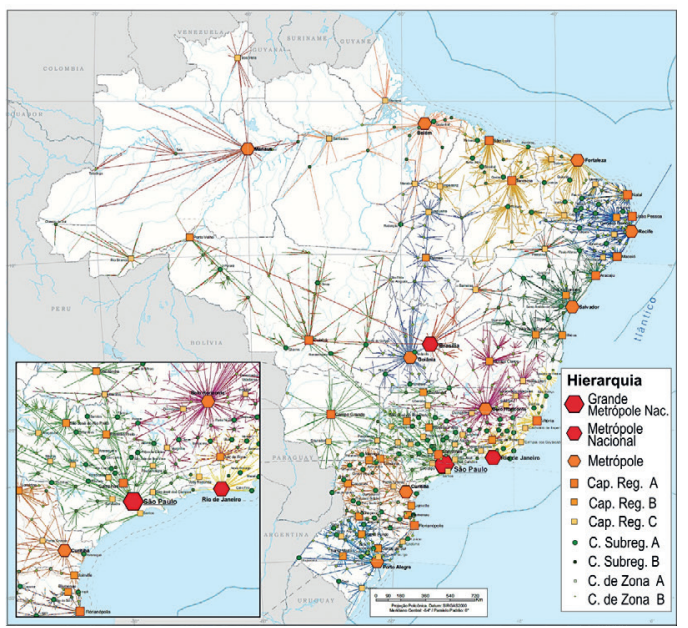

Fonte: IBGE $(2008$, p. 130, 132, 133 e 12)

Elaboração: adaptada por Equipe Fronteiras Ipea.

Entre as mudanças mais expressivas observadas na composição da rede urbana nesses quatro períodos, considerando os ajustes metodológicos das pesquisas, descrevem-se, entre outras, as seguintes. 
1) A importância de Goiânia como principal centralidade do Centro-Oeste, registrada nas pesquisas de 1966 e 1978, com Brasília exercendo o papel de centro regional, sofre abrupta mudança na Regic de 2007, coincidentemente ao ser incorporada a função de gestão do território como elemento relevante na classificação dos centros.

2) As metrópoles Recife e Salvador, na pesquisa de 1966, sustentavam toda a ampla rede de cidades do Nordeste, com importância restrita das centralidades das capitais estaduais a elas subordinadas. A partir de 1978, Fortaleza passa a dividir com essas a coordenação da rede urbana regional, sustentada por um conjunto mais fortalecido de centralidades exercidas pelas capitais de UFs. Observa-se então grande redução na abrangência da região de influência de Recife, cuja centralidade exercida em 1966 influenciava áreas de vários outros estados.

3) As regióes Norte e Sul, em 1966, também tinham uma única centralidade relevante, no caso Belém e Porto Alegre, respectivamente. Em 1978, a pesquisa registra a inserção de Manaus e Curitiba, que passam a compartir com essas a sustentação da rede regional de cidades, permanecendo até 2018, período em que na região Sul é identificada uma terceira metrópole no comando de sua rede urbana, Florianópolis. Nota-se que em 1978 a região de influência de Curitiba estende-se para áreas ao norte do Paraná, antes dominadas pela centralidade de São Paulo, tendo Londrina como protagonista.

4) A característica de redes com poucos centros intermediários e alta centralidade da hierarquia máxima de alguns estados, como se fossem raios de sol a partir de um único centro, mantém-se até a pesquisa de 2007 para as capitais Manaus, São Luís, Teresina, Fortaleza, Brasília, Goiânia, Cuiabá e Campo Grande, sendo predominante no Brasil, especialmente nas regióes Centro-Oeste, Norte e Nordeste.

5) A rede com desenho mais escalonado, considerado de maior equilíbrio pela distribuição das funções entre vários centros intermediários, é evidenciada desde a pesquisa de 1966, para a maior parte dos estados das regióes Sul e Sudeste, particularmente notórias em relação a São Paulo, Rio de Janeiro, Curitiba e Porto Alegre, podendo-se verificar ainda esta característica, embora com menor densidade de centralidades intermediárias, para Belo Horizonte e Salvador, esta na região Nordeste.

6) A partir da pesquisa de 1993, identificam-se novas centralidades intermediárias nas áreas antes com menor densidade de centros, fundamentalmente nos estados de Mato Grosso e Rondônia, indicando a expansão da ocupação do território e a formação de cidades estruturantes da economia pautada no agronegócio.

7) Nessa pesquisa, na rede de Goiânia, destacaram-se duas centralidades, Palmas e Araguaína, no então criado estado de Tocantins.

Algumas permanências também cabem ser apontadas. 
1) Apesar de unir-se ao conjunto metropolitano sem distinção de grau de complexidade, como na classificação das pesquisas de 1978 e 1993, São Paulo mantém a grande extensão de sua regiáo de influência ao longo dos períodos, consolidando o seu papel como a principal metrópole brasileira e conferindo legitimidade à classificação como grande metrópole nacional das pesquisas de 1966, 2007 e 2018.

2) Manutenção da subordinação de algumas capitais brasileiras às metrópoles, reforçando o papel dessas na rede urbana, como o exposto pela leitura da rede de 2007: São Luís e Teresina a Fortaleza; Maceió e Natal a Recife; Aracaju a Salvador; Vitória a Rio de Janeiro; Porto Velho (que abrange Rio Branco) a Brasília; Campo Grande e Cuiabá a São Paulo, sendo a segunda também a Brasília; e Florianópolis a Curitiba.

3) A retomada da subclassificação das metrópoles brasileiras na rede de 2007, nesta pesquisa, em grande metrópole nacional, metrópole nacional e metrópole, admite o grau de especialização das metrópoles brasileiras.

4) Da mesma forma, o desenho da rede de 2007 representa de forma mais precisa a situação da subordinação entre os centros urbanos de níveis intermediários e os da base da hierarquia, ao realizar maior subdivisão das capitais regionais, dos centros sub-regionais e dos centros de zona. Recuperou, em grande medida, a lógica utilizada na pesquisa de 1966, e a comparação entre estes períodos permite verificar a consolidação da rede que então existia, com elevação no nível hierárquico de grande parte das centralidades.

A pesquisa de 2018 identifica novas metrópoles e promove muitas reclassificaçóes em todos os níveis de centros, ampliando a rede de centros locais ao classificar todos os municípios brasileiros (alguns agregados nos APs). As novas metrópoles se sobressaíram entre as capitais regionais por especificidades produtivas e de serviços, que intensificaram seus fluxos econômicos e populacionais, ampliando as ligaçóes entre os centros e a abrangência de suas regióes de influência. Florianópolis tem a especificidade de destacar-se em uma importante região policêntrica, no leste catarinense, que, segundo o IBGE (2020a, p. 15):

se insere em um contexto estadual específico, com diversas Capitais Regionais presentes em Santa Catarina para as quais convergem as ligaçôes das Cidades de menor hierarquia e, a partir dessas Capitais Regionais, estabelece-se a influência de Florianópolis. Trata-se de uma rede bem encadeada, composta por diversos níveis hierárquicos intermediários e Capitais Regionais com grande dinamismo econômico (IBGE, 2020a, p. 15).

Conforme o IBGE (2020a, p. 15), o "ingresso de Campinas no grupo de Metrópoles se deve ao alto dinamismo empresarial existente tanto no núcleo quanto 
na área de influência, bem como ao porte demográfico, que ultrapassa os 2 milhóes de habitantes". Vitória se insere entre as metrópoles com a segunda menor área do conjunto, superior apenas à de Campinas, e sua influência se estende ao sul da Bahia. O aumento de sua atratividade para bens e serviços decorre da movimentação no porto, e das atividades na produção de petróleo, siderurgia e celulose.

Além das quinze metrópoles, que são as principais centralidades urbanas, das quais todas as cidades recebem influência direta, seja de uma ou mais metrópoles simultaneamente, o segundo nível da escala de classificaçáo constitui-se das 97 capitais regionais, que se dividem em A, B e C. Correspondem aos "centros urbanos com alta concentração de atividades de gestáo, mas com alcance menor em termos de regiáo de influência em comparação com as Metrópoles" (IBGE, 2020a, p. 11). São: nove capitais regionais A, que correspondem a capitais estaduais das regiôes Nordeste e Centro-Oeste, exceto o AP de Ribeirão Preto (SP); 24 capitais regionais B que, além das capitais Palmas (TO) e Porto Velho (RO), correspondem a centralidades de referência no interior dos estados; e 64 capitais regionais $C$, que incluem as capitais estaduais Boa Vista (RR), Rio Branco (AC) e o AP de Macapá (AP), todas na região Norte, entre outras cidades. Essas duas categorias são compreendidas nesta análise como componentes do patamar superior da hierarquia urbana brasileira.

Num patamar ora considerado intermediário, encontram-se o terceiro nível da classificação, que se compóe dos 352 centros sub-regionais, sendo 96 do tipo A e 256 do tipo B, com "atividades de gestáo menos complexas (...) e áreas de influência de menor extensão que as das capitais regionais" (IBGE, 2020a, p. 11). Além deste, do quarto nível da hierarquia urbana, os 398 centros de zona, também subdivididos em 147 do tipo A e 251 do tipo B, que se caracterizam "por menores níveis de atividades de gestão, polarizando um número inferior de cidades vizinhas em virtude da atração direta da população por comércio e serviços baseada nas relaçóes de proximidade" (op.cit., p. 13).

No patamar-base da hierarquia urbana, encontram-se os 4.037 centros locais, o equivalente a $82,4 \%$ das unidades urbanas pesquisadas, apresentando "fraca centralidade em suas atividades empresariais e de gestão pública, geralmente tendo outros centros urbanos de maior hierarquia como referência para atividades cotidianas de compras e serviços de sua população, bem como acesso a atividades do poder público e dinâmica empresarial" (IBGE, 2020a, p. 13). 
Comparativamente à pesquisa de 2007, a composição da rede de 2018 sofre acréscimo no número de metrópoles, de capitais regionais $\mathrm{B}$ e $\mathrm{C}$, e centros sub-regionais $\mathrm{A}$ e $\mathrm{B}$, verificando-se nestes últimos o maior acréscimo de unidades, elevando de 79 para 256 (tabela 1). Reduziram-se os números de capitais regionais $\mathrm{A}$, e mais acentuadamente dos centros de zona A e B, que totalizavam 556 unidades e passaram a 398. Nesta mudança, muitos passaram a ser considerados centros locais, como será analisado na sequência, que também tiveram seu número reduzido. Em termos numéricos, pode-se inferir que o período correspondente a esse último intervalo ofereceu condiçóes de qualificação dos centros, principalmente na configuração de um conjunto amplo e bem distribuído de centros sub-regionais.

\section{TABELA 1}

Distribuição das cidades nas hierarquias urbanas (2007 e 2018)

\begin{tabular}{|c|c|c|c|c|}
\hline \multirow{2}{*}{ Níveis e subníveis de centros classificados } & \multicolumn{2}{|c|}{2007} & \multicolumn{2}{|c|}{2018} \\
\hline & Absoluto & $(\%)$ & Absoluto & $(\%)$ \\
\hline Grande metrópole nacional & 1 & 0,02 & 1 & 0,02 \\
\hline Metrópole regional & 2 & 0,04 & 2 & 0,04 \\
\hline Metrópole & 9 & 0,17 & 12 & 0,24 \\
\hline Capital regional A & 11 & 0,21 & 9 & 0,18 \\
\hline Capital regional B & 20 & 0,39 & 24 & 0,49 \\
\hline Capital regional C & 39 & 0,75 & 64 & 1,31 \\
\hline Centro sub-regional $\mathrm{A}$ & 85 & 1,64 & 96 & 1,96 \\
\hline Centro sub-regional $B$ & 79 & 1,53 & 256 & 5,23 \\
\hline Centro de zona A & 192 & 3,71 & 147 & 3,00 \\
\hline Centro de zona B & 264 & 5,10 & 251 & 5,12 \\
\hline Centro local & 4.473 & 86,43 & 4.037 & 82,40 \\
\hline Total & 5.175 & 100,00 & 4.899 & 100,00 \\
\hline
\end{tabular}

Um olhar sobre a rede configurada na pesquisa de 2018 (figura 3) capta de imediato que a estrutura de 2007 se mantém. Mas, ao se deter nas demais classes de centro, notam-se algumas importantes mudanças na escala da hierarquia urbana. Este olhar comparativo é agora facilitado pela mesma lógica de classificação hierárquica adotada nas duas pesquisas, permitindo ater-se em detalhes com maior segurança. Entre muitas observaçóes, destacam-se algumas que se pontuam na sequência. 
Texto para

Discussão

2666 Regic: trajetória, variações e hierarquia urbana em 2018

FIGURA 3

Rede urbana - Brasil (2007 e 2018)

$3 A-2007$

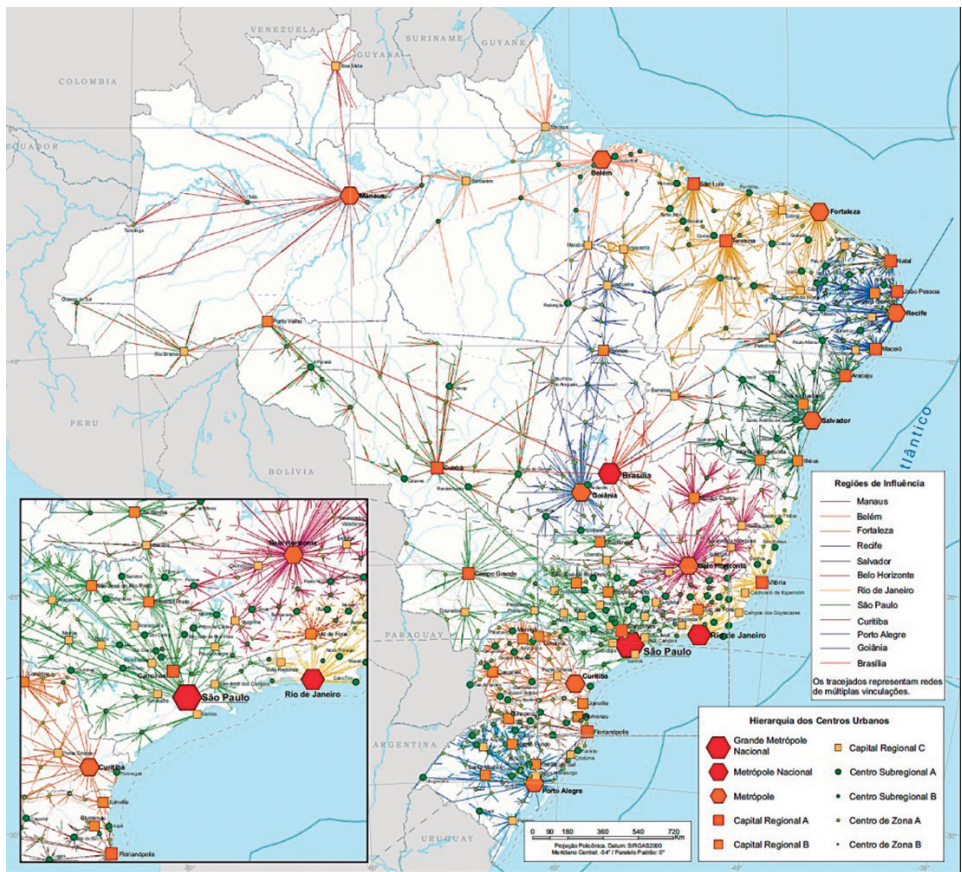

$3 B-2018$

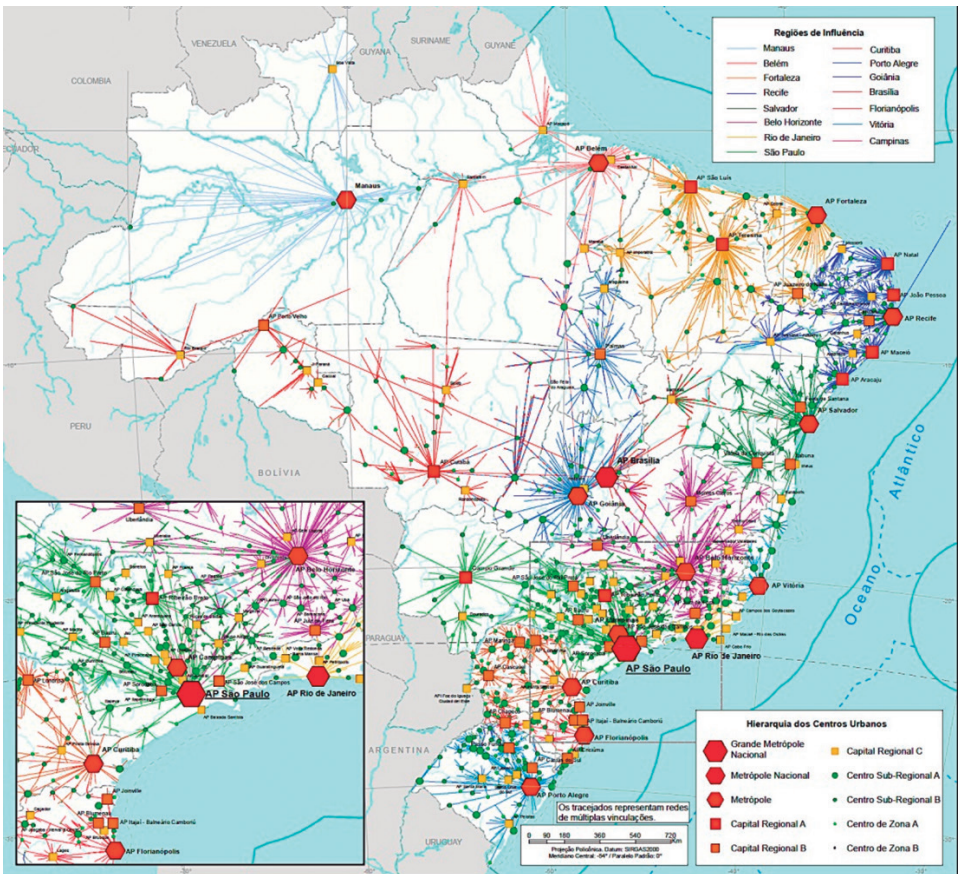

Fontes: IBGE (2008, p. 12: 2020a, p. 12)

Elaboração: adaptada por Equipe Fronteiras Ipea. 
1) Sobressai-se, em primeiro lugar, um maior número de ligações até os centros locais, tornando a representação gráfica muito mais densa.

2) Os feixes de ligaçóes que se voltam para uma centralidade, como raios de sol, ocorrem em grandes regióes com poucas centralidades de nível intermediário, as mesmas destacadas anteriormente, nas regióes Norte e Centro-Oeste, caracterizadas pela grande distância entre os centros, particularmente entre os centros locais e as capitais estaduais.

3) As redes emanadas das metrópoles do Nordeste possuem maior escalonamento até centros intermediários, porém os raios formados ao redor destes demonstram uma polarização direta de vários centros locais ao seu redor. Recentemente, Salvador perdeu inclusive a influência que dividia com Recife sobre a Região Administrativa Integrada de Desenvolvimento (Ride) Petrolina-Juazeiro, e, apesar de ter recuperado a influência sobre Teixeira de Freitas, no sul do estado, perdeu sua mais relevante influência fora do estado (Aracaju). Assim se pode dizer que a influência de Salvador não passa dos limites do estado (apenas de forma indireta pela rede de Vitória da Conquista em pequena parte do norte de Minas Gerais, por exemplo) nem sequer abrange todas as principais hierarquias do estado, tendo ainda casos de compartilhamento de influência, como é o caso de Barreiras, no oeste do estado, dividida com Brasília. Em síntese, atualmente não se pode dizer que Salvador passou a dividir o que antes era a rede de Recife. Historicamente e mantida na atualidade Recife reduziu sua influência por conta de Fortaleza não de Salvador, embora na leitura de Regics anteriores e antes delas a primazia no Nordeste tenha oscilado entre as duas capitais.

4) As redes do Sudeste e Sul demonstram um sistema complexo desde a metrópole até o centro local, formando várias sub-redes intermediárias, passando por capitais regionais, que polarizam centros sub-regionais, que por sua vez polarizam centros de zona e finalmente polarizam centros locais. Ou seja, passam por todos os degraus da hierarquia e em cada um compóem regiōes de influência específicas.

5) A rede urbana de 2018, comparada a de 2007, mostra a transformação de muitos centros locais em centros de zona e de muitos centros de zona em centros sub-regionais, principalmente nas regióes Sul, Sudeste e Nordeste, expondo uma maior densidade de centros em relação à rede de 2007. Grande parte desses obteve a primeira classificação em 2007, como se verá a seguir, e tal reclassificação aponta mais para um ajuste classificatório que para efetivas mudanças nas relaçôes entre cidades.

6) Muitas regiōes encontram-se sob influência de mais de um polo, caso de Barreiras, polarizada por Brasília e Salvador; de municípios do oeste de Mato Grosso, polarizados por Cuiabá e Goiânia; de Petrolina, polarizada por Recife e Fortaleza; de Santarém, polarizada por Belém e Cuiabá; entre outras. 
7) Na região de fronteira, vários municípios elevaram sua posição no nível hierárquico dos centros, e comparativamente se observa que a rede se encontra mais escalonada nos arcos sul e central da fronteira terrestre.

Em 2018, a distribuição dos centros, segundo a classificação na hierarquia, mostra que o maior conjunto metropolitano se localiza na região Sudeste, composto por cinco das quinze metrópoles, entre elas a grande metrópole nacional, São Paulo, e uma das metrópoles nacionais, Rio de Janeiro (tabela 2). Também nessa regiáo concentra-se o maior número das capitais regionais (39,2\% das 97) e dos centros sub-regionais (34,1\% dos 352), segundo a classificação de 2018. Como explica o IBGE (2010, p. 13), essa

concentração ocorre tendo em vista que a região Sudeste sedia grande parte das funções de gestão do país, bem como porção substancial da renda nacional. Essa renda, estando distribuída em diversas cidades presentes na regiâo sudeste, propicia a existência de mercados de nível intermediário para atender ao grande número de consumidores com renda mais elevada.

TABELA 2

População, área e distribuição regional dos níveis de centros, segundo as grandes regiões - Brasil (2018)

\begin{tabular}{|c|c|c|c|c|c|c|c|}
\hline Informações & Unidade & Brasil & Norte & Nordeste & Sudeste & Sul & Centro-Oeste \\
\hline \multirow{2}{*}{$\begin{array}{l}\text { População } \\
2018\end{array}$} & Número de habitantes & 208.494 .900 & 18.182 .253 & 56.760 .780 & 87.711 .946 & 29.754 .036 & 16.085 .885 \\
\hline & $(\%)$ & 100 & 8,7 & 27,2 & 42,1 & 14,3 & 7,7 \\
\hline \multirow{2}{*}{ Área 2018} & $\mathrm{Km} 2$ & 8.510 .821 & 3.851 .281 & 1.551 .991 & 924.565 & 576.743 & 1.606 .239 \\
\hline & $(\%)$ & 100 & 45,3 & 18,2 & 10,9 & 6,8 & 18,9 \\
\hline \multirow{2}{*}{ Metrópole } & Número absoluto & 15 & 2 & 3 & 5 & 3 & 2 \\
\hline & $(\%)$ & 100 & 13,3 & 20,0 & 33,3 & 20,0 & 13,3 \\
\hline \multirow{2}{*}{ Capital regional } & Número absoluto & 97 & 11 & 21 & 38 & 21 & 6 \\
\hline & $(\%)$ & 100 & 11,3 & 21,6 & 39,2 & 21,6 & 6,2 \\
\hline \multirow{2}{*}{$\begin{array}{l}\text { Centro } \\
\text { sub-regional }\end{array}$} & Número absoluto & 352 & 27 & 88 & 120 & 83 & 34 \\
\hline & $(\%)$ & 100 & 7,7 & 25,0 & 34,1 & 23,6 & 9,7 \\
\hline \multirow{2}{*}{ Centro de zona } & Número absoluto & 398 & 21 & 135 & 107 & 90 & 45 \\
\hline & (\%) & 100 & 5,3 & 33,9 & 26,9 & 22,6 & 11,3 \\
\hline \multirow{2}{*}{ Centro local } & Número absoluto & 4.037 & 373 & 1.436 & 1.074 & 819 & 335 \\
\hline & $(\%)$ & 100 & 9,2 & 35,6 & 26,6 & 20,3 & 8,3 \\
\hline
\end{tabular}

Fontes: IBGE (2018a; 2018b; 2020a).

Elaboração: Equipe Fronteiras Ipea.

A maioria dos centros de zona está localizada na regiáo Nordeste (33,9\% dos 398 dessa classe), seguida pela Sudeste (26,9\%). Considerando os centros locais, que compóem a base da hierarquia urbana nessa classificação, os maiores conjuntos repetem essa situação: 35,6\% dos 4.037, na regiāo Nordeste; e 26,6\%, na Sudeste. No caso da primeira, de acordo com o IBGE (2020a, p. 13), 
os centros de zona e centros locais são mais numerosos na região Nordeste, evidenciando a preponderância das relaçóes de proximidade na organização da rede urbana dessa região. A média da renda gerada tem níveis inferiores às da região Sul e Sudeste e a viabilidade de manutenção de mercados intermediários é reduzida, devido ao menor poder de compra dos consumidores.

Há que se considerar também que as regiôes Nordeste e Sudeste são as mais populosas. Estando na primeira 27,2\% dos habitantes do país e na segunda 42,1\%. Enquanto a Nordeste tem a segunda maior grandeza de área, participando com aproximadamente $18 \%$ do território nacional, a Sudeste tem a segunda menor área, 10,9\%, o que faz com que esse elevado número de centralidades torne essa a regiáo com a rede mais densa $\mathrm{e}$ mais complexa, pelo elevado número de centralidades do patamar superior da hierarquia urbana (metrópoles e capitais regionais) e a segunda maior concentração das centralidades do nível intermediário (centros sub-regionais e centros de zona).

A regiáo Sul, com 14,3\% da população e 6,8\% da área territorial brasileira, mantém-se com uma participação quase constante em relação à presença das centralidades, com aproximadamente $20 \%$ de todas as categorias de cidades.

As regióes Norte e Centro-Oeste apresentam participação mais restrita em todas as categorias, o que aponta para redes de baixa densidade e maior distância entre os centros. Mostram que, embora a urbanização efetivamente tenha se interiorizado, a complexidade funcional urbana não se reproduziu equitativamente em todas as grandes regiōes e é elevada a dificuldade de acesso às centralidades funcionalmente mais dotadas, pelas restriçốes dos sistemas de comunicaçôes e transportes, particularmente na região Norte. Com a pandemia em curso, observou-se o que significa, na prática, esse desenho de rede urbana, que explica o motivo pelo qual os sistemas de saúde de alta complexidade de Manaus e Belém se saturaram em táo pouco tempo. Ficou explícita a alta dependência desses serviços por muitos municípios e, além disso, tornou evidente que muitas vidas foram ceifadas em função da longa distância a ser percorrida e da incapacidade logística em se alcançar os equipamentos em tempo hábil para o tratamento necessário.

Ao se analisar a dimensão das redes que emanam das centralidades de primeiro nível, ou metrópoles, como antecipado, a regiáo Sudeste detém cinco redes de primeiro nível, a partir de suas metrópoles. Observa-se na grande metrópole nacional, composta pelo AP de Sáo Paulo, o maior número de todas as categorias de centros, exceto os locais, somando 833 cidades classificadas, para um total de 22,6\% da populaçâo total dessas redes (tabela 3). 
Segundo o IBGE (2020a, p. 13), o "alcance da influência direta de São Paulo ultrapassa o próprio estado, atingindo Mato Grosso do Sul, algumas cidades do norte paranaense, parte do sul de Minas Gerais e triângulo mineiro, onde divide influência com Belo Horizonte". A rede do AP de Belo Horizonte é a terceira mais populosa, com 9,6\% de participaçáo no total da população, e a que concentra o maior conjunto de centros, totalizando 881 cidades classificadas, "caracterizando uma rede complexa com diversos centros de hierarquia intermediária. Ocupa, essencialmente, o estado de Minas Gerais, com inserçôes isoladas nos estados de São Paulo, Rio de Janeiro, Espírito Santo e Goiás" (op. cit., p. 14). A rede do AP do Rio de Janeiro é a quinta mais populosa, abrangendo um conjunto relativamente pequeno de cidades, mas esse centro urbano tem um grande peso na economia, detendo mais de $10 \%$ do produto interno bruto (PIB) nacional, como informa o IBGE (2020a, p. 14), e isso se explica "pela capacidade que suas atividades possuem de atuar em rede, criando ligaçóes de longa distância com outras metrópoles e centros urbanos em todo o território nacional". As redes dos APs de Vitória e Campinas são as menos populosas, ambas participando com $2 \%$ do total da população, pouco extensas e com reduzido número de centros integrantes, sendo a de Campinas com o menor número do conjunto em análise.

TABELA 3

Centralidades e população das redes de primeiro nível (2018)

\begin{tabular}{lcccccc}
\hline Redes de primeiro nível & $\begin{array}{c}\text { Capitais } \\
\text { regionais }\end{array}$ & $\begin{array}{c}\text { Centros } \\
\text { sub-regionais }\end{array}$ & $\begin{array}{c}\text { Centros } \\
\text { de zona }\end{array}$ & $\begin{array}{c}\text { Centros } \\
\text { locais }\end{array}$ & $\begin{array}{c}\text { População } \\
2018\end{array}$ & $\begin{array}{c}\text { Participação } \\
\text { no total da } \\
\text { população' } \\
(\%)\end{array}$ \\
\hline AP São Paulo/SP & 26 & 77 & 51 & 679 & 49.295 .747 & 22,6 \\
AP Brasília/DF & 8 & 25 & 24 & 277 & 11.649 .359 & 5,3 \\
AP Rio de Janeiro/RJ & 5 & 11 & 3 & 63 & 17.296 .239 & 7,9 \\
AP Belém/PA & 4 & 10 & 8 & 157 & 9.335 .660 & 4,3 \\
AP Belo Horizonte/MG & 12 & 52 & 65 & 752 & 21.069 .799 & 9,6 \\
AP Campinas/SP & 1 & 10 & 1 & 34 & 4.396 .180 & 2,0 \\
AP Curitiba/PR & 5 & 30 & 32 & 373 & 11.654 .092 & 5,3 \\
AP Florianópolis/SC & 10 & 16 & 27 & 265 & 7.138 .738 & 3,3 \\
AP Fortaleza/CE & 5 & 34 & 58 & 630 & 20.109 .664 & 9,2 \\
AP Goiânia/GO & 3 & 21 & 34 & 364 & 8.269 .552 & 3,8 \\
Manaus/AM & 1 & 4 & 2 & 71 & 4.490 .260 & 2,1 \\
AP Porto Alegre/RS & 6 & 39 & 37 & 417 & 11.293 .956 & 5,2 \\
AP Recife/PE & 10 & 36 & 45 & 720 & 23.601 .254 & 10,8 \\
AP Salvador/BA & 6 & 24 & 39 & 402 & 14.471 .227 & 6,6 \\
AP Vitória/ES & 1 & 8 & 85 & 4.468 .927 & 2,0 \\
\hline
\end{tabular}

Fontes: IBGE (2018b; 2020a, tabela 2, p. 14).

Elaboração: Equipe Fronteiras Ipea.

Nota: ${ }^{1} \mathrm{~A}$ relação de proporcionalidade foi construída com base na soma do total da população das redes, sabendo-se que algumas redes se sobrepõem, portanto a população total extrapola a população do Brasil em 2018. 
A região Nordeste organiza-se a partir de três importantes redes de primeiro nível. A formada pelo AP de Recife é a segunda mais populosa (10,8\% da população das redes) e terceira no número de cidades classificadas (um total de 811), com elevado número de capitais regionais. A rede do AP de Fortaleza é a quarta mais populosa (9,2\%) e quarta em número total de cidades classificadas (727). Sua rede se destaca "por abarcar diversas Unidades da Federação, total e parcialmente, situando-se no Ceará, Piauí e Maranhão, chegando à parte do oeste pernambucano, Tocantins e Pará” (IBGE, 2020a, p. 15). A rede polarizada pelo AP de Salvador é a que concentra os menores volume de população e conjunto de cidades, entre as três. Sua área não cobre todo o território da Bahia, “uma vez que o oeste foi ‘capturado’ pela rede de Brasília e o norte do Estado pela rede do arranjo populacional de Petrolina/PE-Juazeiro/BA, que pertence à rede de Recife. Entretanto, sua influência se estende além das divisas estaduais, a algumas cidades de Minas Gerais, com centros urbanos fazendo parte das redes das cidades de Teixeira de Freitas (BA) e Vitória da Conquista (BA)” (IBGE, 2020a, p. 16).

As redes das três metrópoles sulinas têm destaque pelo elevado número de cidades classificadas nos níveis superior e intermediário da hierarquia urbana na menor área territorial entre as regióes. A rede do AP de Porto Alegre restringe-se ao próprio estado, enquanto a do AP de Curitiba transcende suas divisas estaduais, particularmente em relação ao norte catarinense e sul de Mato Grosso do Sul. Outra característica destacável é a rede polinuclearizada e fortemente articulada no leste catarinense, e o importante conjunto de centros nos níveis intermediários que se organizam sob o comando de uma das três mais jovens metrópoles brasileiras.

No Centro-Oeste, a rede do AP de Brasília se destaca, "principalmente, por sua extensão que corresponde a mais de $20 \%$ do território nacional" e por sua amplitude, "maior no sentido leste-oeste, abrangendo desde o oeste baiano a partir da rede da capital regional Barreiras (BA), na qual divide influência com a metrópole de Salvador, até a rede da capital regional Rio Branco (AC), compreendendo entre uma e outra os estados de Mato Grosso e Rondônia” (IBGE, 2020a, p. 13). A rede do AP de Goiânia também possui um elevado número de cidades e tem grande extensão, "com alcance sobre algumas cidades do Triângulo Mineiro, seguindo ao norte até abranger quase completamente o Tocantins, com entradas no sudeste paraense e leste de Mato Grosso” (op. cit., p. 15-16).

Também se destacam pela extensão as redes dos APs de Manaus e Belém, estruturando-se ao longo de rodovias e hidrovias, em região de municípios de elevado porte,

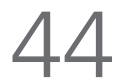


induzindo a um menor número de cidades classificadas. Manaus, única metrópole que não configura um $\mathrm{AP}$, tem sua rede marcada pela fraca existência de níveis intermediários de centros e pelas distâncias entre eles. Apresenta "longas ligaçóes convergindo, quase totalmente, para a sede de sua área de influência, atravessando o estado do Amazonas. A média de distância das ligaçôes presentes na rede urbana de Manaus não apenas é a maior apresentada pelas redes de primeiro nível, como soma mais que o dobro das distâncias médias da segunda maior colocada: são conexôes de 316 km, em média, entre as cidades da rede urbana de Manaus, enquanto a rede de Brasília, com a segunda maior distância média, apresenta 145 km" (IBGE, 2020a, p. 16). A rede do AP de Belém também se destaca por ser "a terceira rede mais extensa (após Brasília e Manaus), e abrange, sobretudo, os estados do Pará e Amapá, com algumas cidades próximas maranhenses e uma tocantinense" (op. cit., p. 14).

\subsection{Variação nos níveis de centralidade}

\subsubsection{Procedimentos operacionais}

Para se apreender mais detidamente a evolução dos níveis de classificação das cidades centrais da rede urbana brasileira, os dados dos municípios referentes às classificaçóes em todas as escalas da hierarquia urbana, disponibilizados no conjunto de produtos da Regic 2018 (IBGE, 2020a), foram organizados para permitir comparabilidade desde a primeira pesquisa realizada pelo IBGE. A partir desses dados e para sua comparação, foi realizado um exercício de correspondência entre os níveis, similar ao realizado para o metropolitano, abordado na seção 3.3 deste trabalho.

Partiu-se, primeiramente, de ajustar a numeraçáo das classes de centros de acordo com os níveis de cada escala, procurando respeitar ao máximo a numeração fornecida pelo IBGE, que acompanha as diferentes nomenclaturas das classificaçōes. Foram mantidas as numeraçôes das pesquisas de 1966, 2007 e 2018, e alteradas, em correspondência a essas, as referentes às pesquisas de 1978 e 1993 (quadro 3).

$\mathrm{Na}$ classificação de 1978, pelas características apresentadas no quadro 3, os níveis de centro submetropolitano, numerado como 2, e de capital regional, numerado como 3, passaram a integrar o mesmo nível 2, desmembrando-se em 2a e 2b; sucessivamente, o nível de centro sub-regional, numerado como 4, passou a 3, e o de centro de zona, numerado como 5 , passou a 4, respeitando as numeraçôes dos níveis nos demais 
períodos. Com isso, ganharam comparabilidade com as demais classificaçóes. Observa-se que os municípios subordinados não foram identificados na planilha disponibilizada.

QUADRO 3

Numeração dos níveis e subníveis dos centros para efeito de análise

\begin{tabular}{|c|c|c|c|c|}
\hline Regic 1966 & Regic 1978 & Regic 1993 & Regic 2007 & Regic 2018 \\
\hline 1a Grande metrópole nacional & 1 Metrópole regional & 1 Máximo & $\begin{array}{c}\text { 1a Grande metrópole } \\
\text { nacional }\end{array}$ & $\begin{array}{c}\text { 1a Grande metrópole } \\
\text { nacional }\end{array}$ \\
\hline 1b Metrópole nacional & - & - & 1b Metrópole nacional & 1b Metrópole nacional \\
\hline 1c Centro metropolitano regional & - & - & 1c Metrópole & 1c Metrópole \\
\hline 1d Centro macrorregional & - & - & - & - \\
\hline 2a Centro regional & $\begin{array}{c}\text { 2a Centro } \\
\text { submetropolitano }\end{array}$ & 2a Muito forte & 2a Capital regional A & 2a Capital regional A \\
\hline $2 \mathrm{~b}$ Centro regional B & 2b Capital regional & $2 b$ Forte & 2b Capital regional B & 2b Capital regional B \\
\hline- & - & - & 2c Capital regional C & 2c Capital regional C \\
\hline 3a Centro sub-regional $\mathrm{A}$ & 3 Centro sub-Regional & 3a Forte para médio & 3a Centro sub-regional A & 3a Centro sub-regional A \\
\hline $3 b$ Centro sub-regional $B$ & - & 3b Médio & $3 b$ Centro sub-regional B & $3 b$ Centro sub-regional B \\
\hline 4a Centro local A & 4 Centro de zona & 4a Médio para fraco & 4a Centro de zona A & 4a Centro de zona A \\
\hline 4b Centro local B & - & 4b Fraco & 4b Centro de zona B & 4b Centro de zona B \\
\hline - & - & - & 5 Centro local & 5 Centro local \\
\hline
\end{tabular}

Fontes: IBGE (2008; 2020a).

Elaboração: Equipe Fronteiras Ipea.

Em relação à classificação de 1993, por diferir mais das anteriores e posteriores, fez-se uma análise de correspondência das cidades que integravam cada nível, o que permitiu chegar à numeração proposta. A numeração foi primeiramente invertida, posto que nessa escala o maior número, 8 , cabe às metrópoles, que são as únicas centralidades com o nível máximo, usualmente numeradas por 1; na sequência, os níveis muito forte (7) e forte (6) foram considerados como 2, por terem forte correspondência com as capitais regionais, subdividindo-se em 2 a e 2 b; forte para médio (5) e médio (4), com similar aderência aos centros sub-regionais, obtiveram a numeração $3 \mathrm{a}$ e $3 \mathrm{~b}$; médio para fraco (3) e fraco (2) tornaram-se 4a e 4b. Nenhuma classe de centro havia sido numerada em 1. Mantiveram-se assim, cinco classes de cidades e suas subdivisóes, devidamente passíveis de uma correspondência mais direta.

Renumerados os campos na planilha, foi realizada a leitura de correspondência das classificaçôes para todos os municípios brasileiros. Três circunstâncias foram considera- 
das: a primeira é que nos períodos iniciais da pesquisa foi classificado apenas um recorte determinado de municípios, seja por porte populacional mais significativo ou por indicar centralidade extramunicipal. A totalidade dos municípios apenas passou a ser considerada nas duas últimas pesquisas, sendo responsável pelo expressivo número de centros locais. Para esses dois últimos períodos, realizou-se uma leitura detalhada da variação.

Como segunda circunstância, considerou-se que a malha municipal brasileira sofreu sucessivos desmembramentos de municípios, o que poderia ou náo influir na classificação ao longo dos períodos. No entanto, a reconstituição dessa malha, que demandaria um sobretrabalho a esta leitura de resultados, não se mostrou imprescindível, posto que a maioria dos municípios emancipados no período situou-se entre aqueles não classificados, nos períodos iniciais da pesquisa, ou classificados como centros locais nos dois últimos períodos. Os municípios que se desmembraram foram analisados ao longo do período e seu desempenho se deve a mais fatores que apenas ao processo de fragmentação territorial.

A terceira circunstância considerada é que, dos 5.570 municípios brasileiros, 960 foram computados em APs, resultando em um total de 4.899 unidades territoriais denominadas pelo estudo como "cidades". Essas cidades correspondem aos 289 APs (289 cidades-polo mais 671 municípios polarizados, totalizando os 960 municípios) e 4.610 unidades municipais que não se configuram ou integram APs. Nesse caso, a classificação nos períodos foi registrada apenas na cidade-polo.

A leitura das correspondências evidenciou quatro situaçóes: i) estabilidade nos níveis durante todo o período; ii) oscilaçôes entre níveis, mas com manutenção do original; iii) elevação de nível; e iv) queda de nível. A primeira, estável no nível atual, agrega os municípios ou APs que desde a pesquisa de 1966 se mantiveram no mesmo nível de classificação (metrópole, centros ou capitais regionais, centros sub-regionais, centros locais, em 1966, ou de zona nas demais), mesmo que tenham oscilado entre as subclassificações do respectivo nível. A segunda condição, com elevação de nível, significa que a unidade atingiu o nível atual durante os períodos analisados, não importando se foi uma ascensão contínua, abrupta, no início ou no fim dos períodos considerados. Capta-se, portanto, que o município ou AP deixa o nível inicial para elevar-se a outro nível, até ou em 2018. A terceira condição, oscilações com manutenção do nível original, refere-se aos municípios ou APs que oscilaram sua classificação nos períodos, 
mas iniciaram e terminaram no mesmo nível. A quarta condição, de queda de nível, corresponde ao município ou AP que baixou o nível de classificação durante o período, não importando se foi uma queda contínua, abrupta, no início ou no fim dos períodos analisados. Corresponde, pois, ao município ou arranjo que deixa o nível inicial em direção a um patamar de nível inferior, até ou em 2018. Na sequência, essas condiçôes serão analisadas.

\subsubsection{Distribuição territorial das mudanças e permanências}

A distribuição das cidades nessas condiçôes de mudanças ou permanências, segundo o nível de classificação em 2018, mostra a ocorrência de uma grande estabilidade em todos os níveis de centralidade, particularmente entre os centros de zona e as capitais regionais, sendo que no total do país essa condição ocorre em 80,3\% das cidades consideradas (tabela 4). As oscilaçôes no período, sem mudança entre o nível inicial e o de 2018, prevalecem nos centros sub-regionais e centros de zona, dando-se em apenas 3,6\% das cidades. A elevação de nível, correspondendo à condição de $6,7 \%$ das cidades pesquisadas, dá-se majoritariamente em relação às capitais regionais e aos centros sub-regionais, enquanto as quedas de nível ocorrem, fundamentalmente, em relação a alguns centros locais, que outrora conquistaram posição em níveis como centros sub-regionais ou centros de zona, e nessa condição de mudança encontram-se $8,5 \%$ das cidades brasileiras.

Ao se considerar a localização no território das cidades, segundo essas condiçóes de mudança na escala da hierarquia urbana, observa-se uma ampla distribuição territorial em relação aos municípios que se mantiveram em estabilidade ou oscilação, sem alteração dos níveis de classificação (mapa 2). ${ }^{16}$ As condições de elevação ou queda nos níveis de classificação também estão distribuídas no território, registrando ocorrências nas cinco grandes regióes brasileiras.

16. Para facilitar a leitura da distribuição das condições de mudanças e permanências, os centros locais foram excluídos da representação cartográfica, dado o elevado número de municípios nessa classificação que se mantiveram na condição de estáveis no período $(89,6 \%$ ) e o fato de terem sido introduzidos como unidades de base da pesquisa apenas em 2007. 
TABELA 4

Distribuição das cidades por nível de classificação, segundo condições de evolução do nível de centralidade - Brasil (1966-2018)

\begin{tabular}{|c|c|c|c|c|c|c|c|c|c|c|c|c|}
\hline \multirow{3}{*}{ Nível em 2018} & \multicolumn{8}{|c|}{$\begin{array}{c}\text { Condição } \\
(1966-2018)\end{array}$} & \multirow{2}{*}{\multicolumn{2}{|c|}{$\begin{array}{l}\text { Classificado só } \\
\text { em } 2018\end{array}$}} & \multirow{2}{*}{\multicolumn{2}{|c|}{ Total }} \\
\hline & \multicolumn{2}{|c|}{ Estável } & \multicolumn{2}{|c|}{ Elevação } & \multicolumn{2}{|c|}{ Oscilação } & \multicolumn{2}{|c|}{ Queda } & & & & \\
\hline & Número & $(\%)$ & Número & $(\%)$ & Número & $(\%)$ & Número & $(\%)$ & Número & $(\%)$ & Número & $(\%)$ \\
\hline Metrópole & 9 & 60,0 & 5 & 33,3 & 1 & 6,7 & 0 & 0,0 & 0 & 0,0 & 15 & 100 \\
\hline Capital regional & 39 & 40,2 & 43 & 44,3 & 11 & 11,3 & 0 & 0,0 & 4 & 4,1 & 97 & 100 \\
\hline Centro sub-regional & 48 & 13,6 & 196 & 55,7 & 84 & 23,9 & 10 & 2,8 & 14 & 4,0 & 352 & 100 \\
\hline Centro de zona & 218 & 54,8 & 86 & 21,6 & 80 & 20,1 & 12 & 3,0 & 2 & 0,5 & 398 & 100 \\
\hline Centro local & 3.619 & 89,6 & 0 & 0,0 & 0 & 0,0 & 393 & 9,7 & 25 & 0,6 & 4.037 & 100 \\
\hline Total & 3.933 & 80,3 & 330 & 6,7 & 176 & 3,6 & 415 & 8,5 & 45 & 0,9 & 4.899 & 100 \\
\hline
\end{tabular}

Fonte: IBGE (2020a).

Elaboração: Equipe Fronteiras Ipea.

MAPA 2

Variação da classificação dos níveis da hierarquia urbana - Brasil (1966-2018)

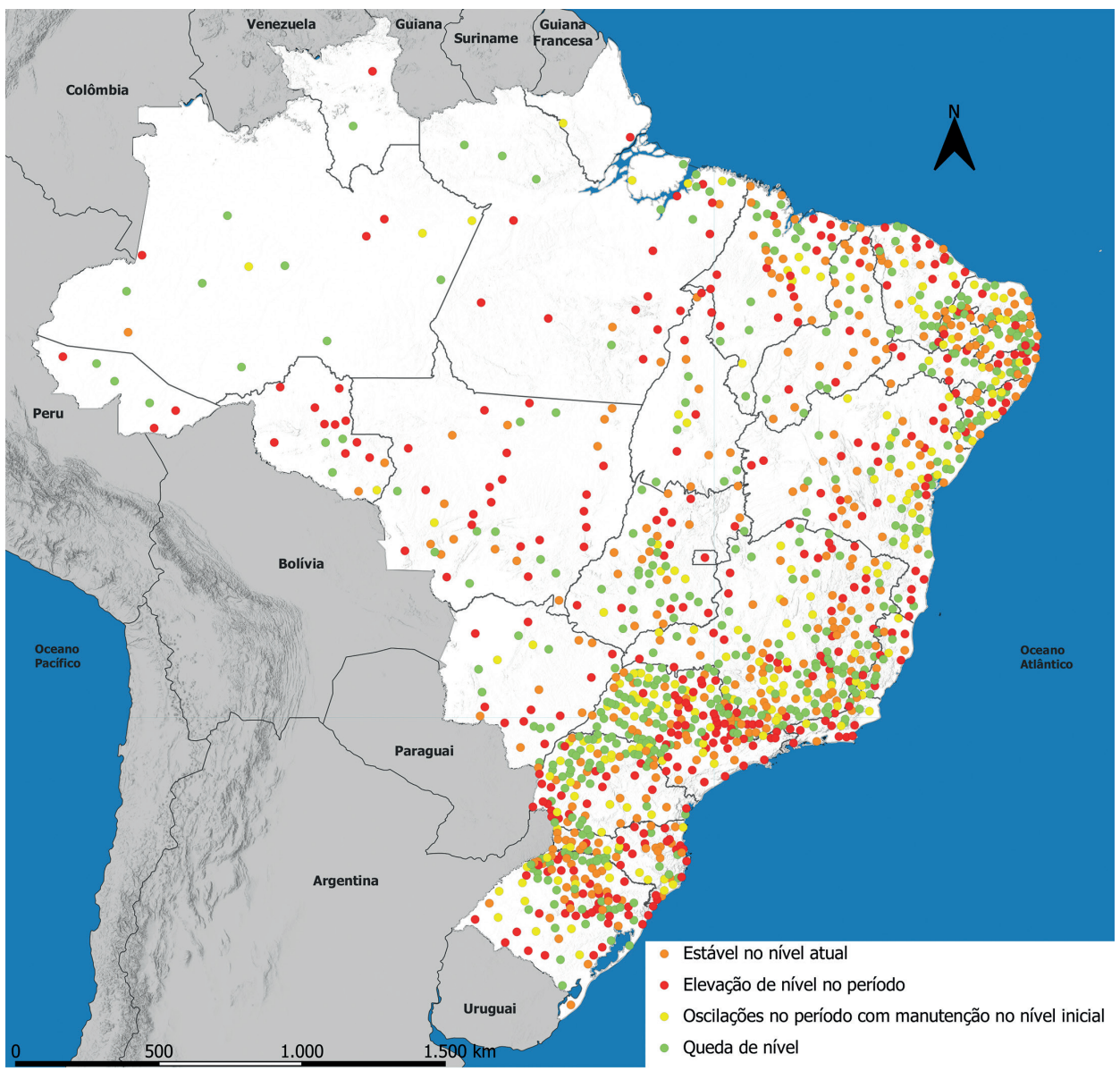

Fonte: IBGE (2020a)

Elaboração: Equipe Fronteiras Ipea.

Obs.: 1. Não inclui centros locais. 
Ao se debruçar sobre esses dados, pode-se detalhar algumas localizaçóes predominantes. As cidades em condição estável e em oscilação, ao longo do período, situam-se de maneira mais concentrada em relação total do país nas regiōes Nordeste (36,1\% e 29,5\%, respectivamente) e Sudeste (26\% e 35,8\%), seguidas pela Sul (20,4\% e 24,4\%) - tabela 5.

TABELA 5

Distribuição dos municípios por condição de evolução na hierarquia urbana, segundo grandes regiões - Brasil (2018)

\begin{tabular}{|c|c|c|c|c|c|c|c|}
\hline Região/condição & & Estável & Elevação & Oscilação & Queda & $\begin{array}{l}\text { Classificado } \\
\text { só em } 2018\end{array}$ & Total \\
\hline & Número & 355 & 36 & 10 & 31 & 2 & 434 \\
\hline \multirow[t]{3}{*}{ Norte } & Região (\%) & 81,8 & 8,3 & 2,3 & 7,1 & 0,5 & 100,0 \\
\hline & Brasil (\%) & 9,0 & 10,9 & 5,7 & 7,5 & 4,4 & 8,9 \\
\hline & Número & 1.420 & 82 & 52 & 122 & 7 & 1.683 \\
\hline \multirow[t]{3}{*}{ Nordeste } & Região (\%) & 84,4 & 4,9 & 3,1 & 7,2 & 0,4 & 100,0 \\
\hline & Brasil (\%) & 36,1 & 24,8 & 29,5 & 29,4 & 15,6 & 34,4 \\
\hline & Número & 1.023 & 96 & 63 & 137 & 25 & 1.344 \\
\hline \multirow[t]{3}{*}{ Sudeste } & Região (\%) & 76,1 & 7,1 & 4,7 & 10,2 & 1,9 & 100,0 \\
\hline & Brasil (\%) & 26,0 & 29,1 & 35,8 & 33,0 & 55,6 & 27,4 \\
\hline & Número & 804 & 73 & 43 & 87 & 9 & 1.016 \\
\hline \multirow[t]{3}{*}{ Sul } & Região (\%) & 79,1 & 7,2 & 4,2 & 8,6 & 0,9 & 100,0 \\
\hline & Brasil (\%) & 20,4 & 22,1 & 24,4 & 21,0 & 20,0 & 20,7 \\
\hline & Número & 331 & 43 & 8 & 38 & 2 & 422 \\
\hline \multirow[t]{3}{*}{ Centro-Oeste } & Região (\%) & 78,4 & 10,2 & 1,9 & 9,0 & 0,5 & 100,0 \\
\hline & Brasil (\%) & 8,4 & 13,0 & 4,5 & 9,2 & 4,4 & 8,6 \\
\hline & Número & 3.933 & 330 & 176 & 415 & 45 & 4.899 \\
\hline \multirow[t]{2}{*}{ Brasil } & Na condição (\%) & 80,3 & 6,7 & 3,6 & 8,5 & 0,9 & 100,0 \\
\hline & Brasil (\%) & 100,00 & 100,00 & 100,00 & 100,00 & 100,00 & 100,00 \\
\hline
\end{tabular}

Fonte: IBGE (2020a).

Elaboração: Equipe Fronteiras Ipea.

Cabe destacar as mudanças relativas às perdas e aos ganhos. As condiçóes de elevação e queda também estão proporcionalmente mais concentradas nessas mesmas regiốes, porém ambas majoritariamente na Sudeste, que responde por 29,1\% dos municípios com elevação de nível e 33\% dos com queda. Verifica-se nas regióes Norte e Centro-Oeste uma importante participação no caso dos municípios em elevação de nível, respectivamente, com 10,9\% e 13\% do total dos municípios tipificados nessa condição. Na condição de queda, em ambas, situam-se menos de $10 \%$ dos municípios assim tipificados no país.

Essa distribuição reproduz espacialmente a heterogeneidade da malha municipal brasileira: todas as condiçôes estão de alguma forma mais concentradas nas porçôes em 
que predominam um maior número de municípios, com menores áreas e maior contingente populacional, portanto nas porçóes mais fragmentadas e mais adensadas do território, fundamentalmente no Sul e Sudeste (mapa 2).

Internamente às grandes regióes, as cidades em condiçãa de estabilidade estão entre $76,1 \%$ e $84,4 \%$ dos totais regionais, predominando com o percentual mais elevado a regiâo Nordeste (tabela 5). As cidades que oscilaram ao longo do período sem mudança de nível perfazem mais de $4 \%$ nas regiôes Sudeste e Sul, enquanto nas demais estão abaixo da participação média brasileira.

As regiōes Norte e Centro-Oeste têm na condição em elevação percentuais bastante superiores ao médio do país, $6,7 \%$, sendo esse o segundo conjunto entre o total de municípios classificados em ambas as regióes, respectivamente 8,3\% e 10,2\%. Apenas a região Nordeste se posiciona abaixo da média brasileira, com apenas 4,9\% dos municípios com elevação no nível da hierarquia urbana. Os municípios com queda nos níveis de centralidade acima da média do país situam-se nas regióes Sudeste (10,2\% de seus municípios), Centro-Oeste (9\%) e Sul (8,6\%).

Há que se chamar a atenção para a relação estabelecida entre os totais de cidades que tiveram elevação e queda no nível de classificaçóes dos centros entre as pesquisas de 1966 e 2018. No Brasil, 330 cidades tiveram elevação de nível, enquanto 415 tiveram queda, o que aponta para rearranjos na dinâmica econômica e social dessas cidades em relação ao conjunto brasileiro. Em termos regionais, apenas o Norte e o Centro-Oeste tiveram um número maior de cidades com elevação do que com queda nos níveis de classificação. As demais regiôes registram mais cidades com queda do que com elevação nos níveis de classificação no período.

Espacialmente, observa-se que as cidades com elevação de nível na classificação estão dispostas majoritariamente ao longo do sistema viário principal (rodovias federais e hidrovias) e nas interligaçóes entre essas, pelas principais vias estaduais (mapa 3). Verifica-se também que um grande número de cidades nessa condição de evolução na escala da rede urbana integra APs, como será considerado no próximo subitem. Embora essa ocorrência se dê fundamentalmente em relação aos APs polarizados por metrópoles, nos quais abrange algumas cidades do seu entorno, dá-se ainda entre os polarizados por capitais regionais e centros sub-regionais, e menos intensamente nos demais, nos novos APs. Ocorre também em cidades que não compóem APs, entre as quais capitais estaduais da região Norte. Outro conjunto de cidades nessa condição é encontrado em áreas de expansão da fronteira econômica, principalmente 
induzida pelo agronegócio, como se observa em porçôes das regióes Centro-Oeste, Norte e Nordeste, também com proximidade aos sistemas de circulação e escoamento da produção. Pode-se inferir que a maioria das cidades em elevação na condição de centralidade guarda relação direta com a intensificação das relaçóes econômicas e sociais em áreas com elevada urbanização e maior integração às dinâmicas principais da economia nacional e internacional.

MAPA 3

Cidades com elevação nos níveis de classificação na hierarquia urbana - Brasil (1966-2018)

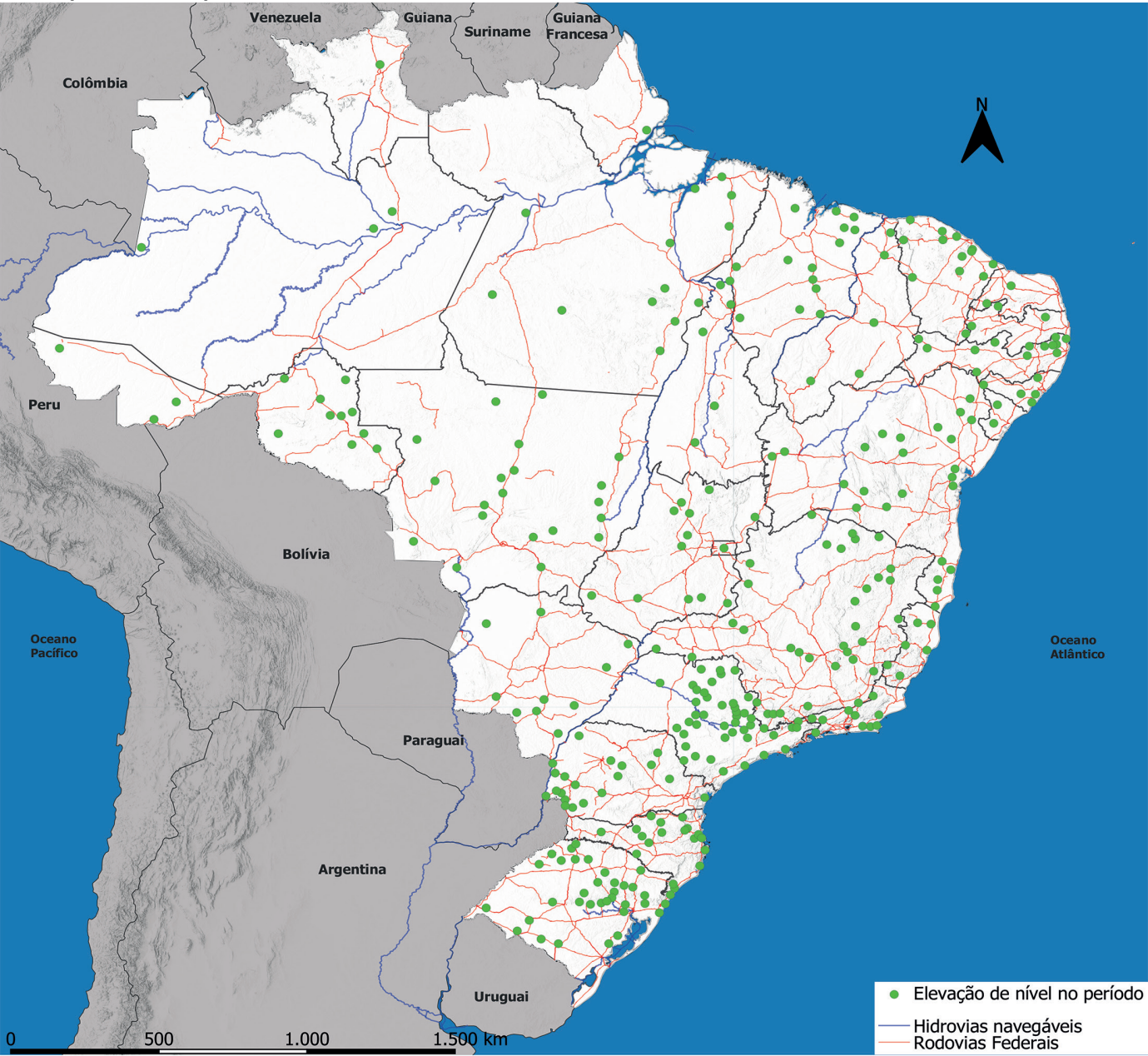

Fonte: IBGE (2020a).

Elaboração: Equipe Fronteiras Ipea.

As cidades com quedas nos níveis de classificação são observadas notadamente em áreas tradicionais de predominância de atividades agropecuárias e agroindustriais, como nas porçôes do interior de São Paulo, noroeste do Rio Grande do Sul, oeste paranaense e 
catarinense, e sul goiano (mapa 4). Imiscuem-se ainda em cidades do continuum da linha da costa atlântica a partir do estado do Rio de Janeiro em direção ao Nordeste e Norte do país. Há que se ir em busca de compreender os motivos distintos que provocaram esse declínio na escala urbana, podendo decorrer tanto de uma situação de deterioração das atividades locais, de reposicionamentos escalares na rede regional, levando a um rebaixamento relativo na classificação de algumas cidades, entre outros. Alguns casos de quedas podem ser atribuídos a ajustes na classificação de cidades que passaram a compor a hierarquia a partir de 2007 , como será abordado no próximo subitem.

MAPA 4

Cidades com queda nos níveis de classificação na hierarquia urbana - Brasil (1966-2018)

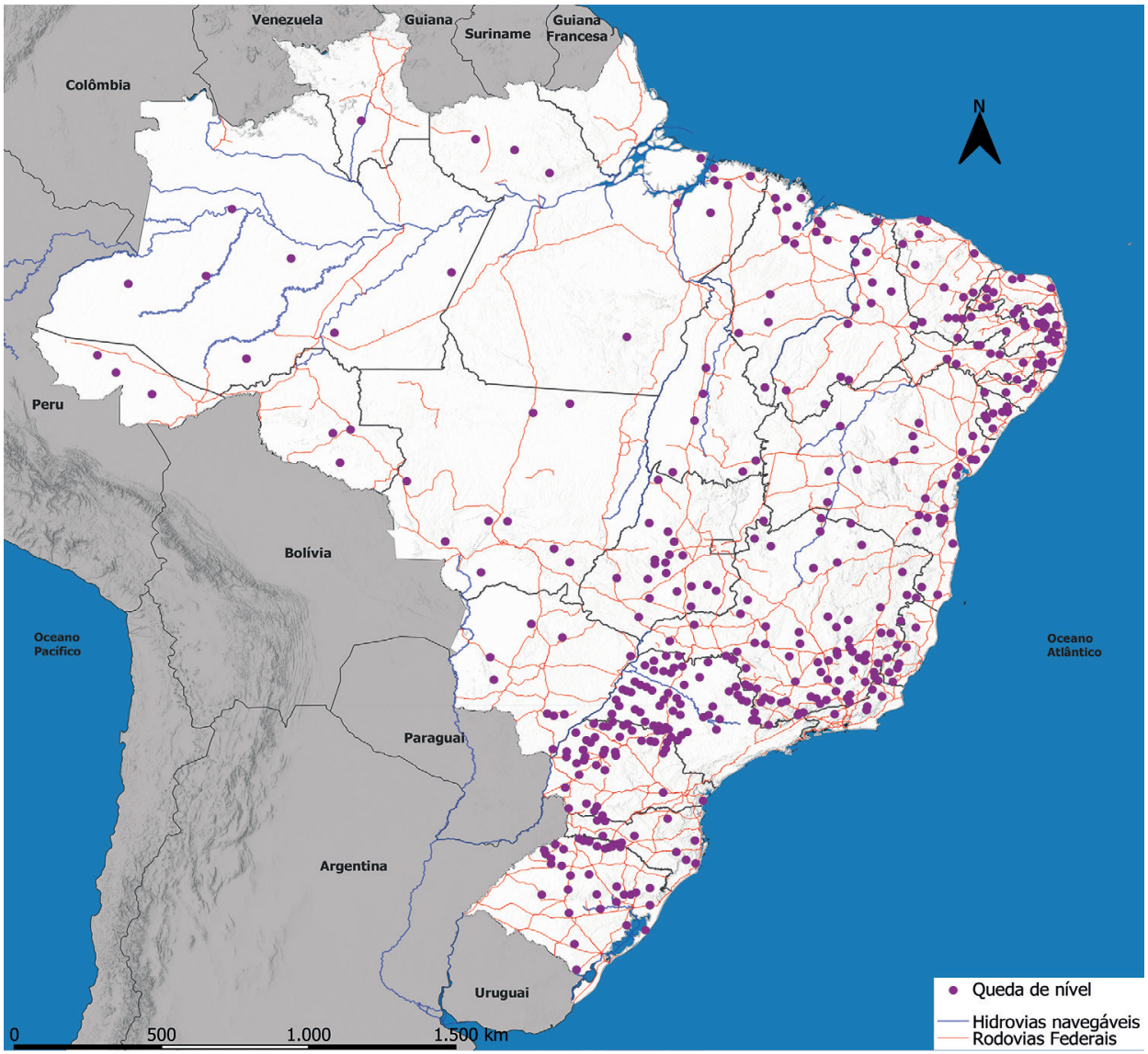

Fonte: IBGE (2020a).

Elaboração: Equipe Fronteiras Ipea.

\subsubsection{Detalhes sobre a variação dos municípios a partir de 2007}

Na pesquisa Regic de 2007, foram incluídos todos os municípios da malha territorial brasileira, ampliando numericamente os classificados. Nessa inclusão, um expressivo conjunto 
de municípios foi classificado como centro local, ou seja, passaram a integrar, com essa denominação, a base da hierarquia. Outros municípios, pelo fato de fazerem parte de ACPs, como explicado na subseção 2.2 deste trabalho, passaram a compor uma unidade com o conjunto dessas áreas de concentração populacional, deixando de ser classificados. Essas mudanças criaram tanto rupturas quanto inserçóes na linha de evolução dos municípios, motivos pelos quais se considerou importante uma abordagem específica a esses períodos.

Assim, dois recortes de análise foram objeto de destaque no comparativo entre as classificações de 2007 e 2018. O primeiro contemplou em separado o conjunto dos municípios classificados apenas a partir da pesquisa de 2007, entre os quais náo se registrou a ocorrência de metrópole, capital regional ou centro sub-regional. Nesse conjunto, um número significativo de municípios foi inserido na classificação basilar da hierarquia urbana, qual seja, a de centro local, que reuniu 3.713 municípios. Desses, 97,5\% mantiveram-se na mesma posição na classificação de 2018; 2,3\% tiveram elevação de nível, passando a integrar os centros de zona; e 0,2\%, ou oito municípios, alcançou o nível de centro sub-regional (tabela 6). Este último caso aponta para um reescalonamento relevante, correspondente a cinco APs, sendo três no Sul (APs de Itapema/SC, de Canela-Gramado/RS e de Charqueadas-Triunfo-São Jerônimo/RS) e dois no Sudeste (APs de Cerquilho-Tietêl SP e de Nova Serrana/MG), e aos municípios Luís Eduardo Magalhães (BA), Pitangueiras (SP) e Fraiburgo (SC).

TABELA 6

Condição da variação nos níveis de classificação (2007)

\begin{tabular}{|c|c|c|c|c|c|c|}
\hline \multirow{3}{*}{ Condição } & \multicolumn{4}{|c|}{ Nivel na Regic 2007} & & \\
\hline & \multicolumn{2}{|c|}{$\begin{array}{l}\text { Centro de zona } \\
\text { (4) }\end{array}$} & \multicolumn{2}{|c|}{$\begin{array}{l}\text { Centro local } \\
\text { (5) }\end{array}$} & \multicolumn{2}{|c|}{ Total } \\
\hline & Número & $(\%)$ & Número & $(\%)$ & Número & $(\%)$ \\
\hline Estável & 53 & 41,7 & 3.619 & 97,5 & 3.672 & 95,6 \\
\hline \multicolumn{7}{|l|}{ Elevação } \\
\hline * De 4 para 3 & 10 & 7,9 & 0 & 0 & 10 & 0,3 \\
\hline * De 5 para 3 & 0 & 0 & 8 & 0,2 & 8 & 0,2 \\
\hline * De 5 para 4 & 0 & 0 & 86 & 2,3 & 86 & 2,2 \\
\hline \multicolumn{7}{|l|}{ Queda } \\
\hline * De 4 para 5 & 64 & 50,4 & 0 & 0 & 64 & 1,7 \\
\hline Total & 127 & 100 & 3.713 & 100 & 3.840 & 100 \\
\hline
\end{tabular}

Fonte: IBGE (2020a).

Elaboração: Equipe Fronteiras Ipea. 
Entre as cidades classificadas como centros de zona, 41,7\% permaneceram estáveis nesse nível, e 50,4\% tiveram queda de nível, passando a se integrar entre os centros locais. Neste caso, supóe-se que de fato houve um ajuste na classificação inicial e não, efetivamente, alteraçôes de nível na hierarquia.

Dos centros de zona, 7,9\%, ou dez cidades, obtiveram elevação para o nível de centro sub-regional, sendo um AP sulino (Tramandaí - Osório/RS) e nove municípios, dos quais seis são de Mato Grosso (Água Boa, Lucas do Rio Verde, Nova Mutum, Pontes e Lacerda, Primavera do Leste e Sorriso), além de Açailândia (MA), Aracruz (ES) e Extrema (MG).

Outro recorte de análise para as duas últimas pesquisas enfocou as variaçóes correspondentes à elevação nos níveis de centralidade em cada grande região e UF e a incidência dos APs nesses casos. A opção por esse recorte foi buscar indícios que sinalizem a associação dessas configuraçôes, comuns na metropolização contemporânea, a um aproveitamento das sinergias dos espaços aglomerados ou fortemente conectados. Como antecipado no subitem anterior, constatou-se que no conjunto de cidades brasileiras que obtiveram elevação no nível de centralidade entre a pesquisa de 2007 e a de 2018, totalizando 437 cidades, 92 (21,1\%) configuram APs (tabela 7). Nas regióes mais urbanizadas, Sudeste e Sul, essa proporção se eleva. Na primeira, ela corresponde a 30\%, e no Sul, a $25 \%$. Chama a atenção o reduzido número de APs entre as cidades da região Nordeste com elevaçáo nos níveis de classificação, dado que significam apenas $6 \%$ dos casos.

TABELA 7

Cidades com elevação no nível de classificação e casos em arranjos populacionais, segundo grandes regiões - Brasil (2007-2018)

\begin{tabular}{lccc}
\hline Região & Número de cidades & Número de APs & $\begin{array}{c}\text { APs/cidades } \\
(\%)\end{array}$ \\
\hline Norte & 25 & 4 & 16,0 \\
Nordeste & 102 & 6 & 5,9 \\
Sudeste & 155 & 46 & 29,7 \\
Sul & 107 & 27 & 25,2 \\
Centro-Oeste & 48 & 9 & 18,8 \\
Brasil & 437 & $\mathbf{9 2}$ & $\mathbf{2 1 , 1}$ \\
\hline
\end{tabular}

Fonte: IBGE (2020a)

Elaboração: Equipe Fronteiras Ipea. 
Em relação aos estados, no Acre e Amapá, na região Norte, 100\% das cidades com elevação do nível de classificação correspondem a APs, respectivamente, AP Internacional de Cobija (Bolívia) - Brasiléia (AC), e AP Laranjal do Jari (AP) - Almeirim (PA). Anota-se que no Amazonas, também obteve elevação a cidade de Tabatinga, que configura um arranjo transfronteiriço com Letícia, na Colômbia, embora esse não tenha sido identificado como $\mathrm{AP}$ internacional entre os relacionados na pesquisa de 2018 (IBGE, 2020a). No Sudeste, o Rio de Janeiro apresenta a maior proporção de correspondência, pois $66,7 \%$ das cidades com elevação de nível correspondem a APs. Vêm na sequência Santa Catarina (40\%), São Paulo (37\%) e Goiás (29\%). Não se verificaram correspondências nos estados de Amazonas e Rondônia, na região Norte, e Bahia, Ceará, Pernambuco e Piauí, na região Nordeste (gráfico 1).

\section{GRÁFICO 1}

Distribuição das cidades com elevação no nível de classificação e casos ocorridos em arranjos populacionais, segundo UFs - Brasil (2007-2018)

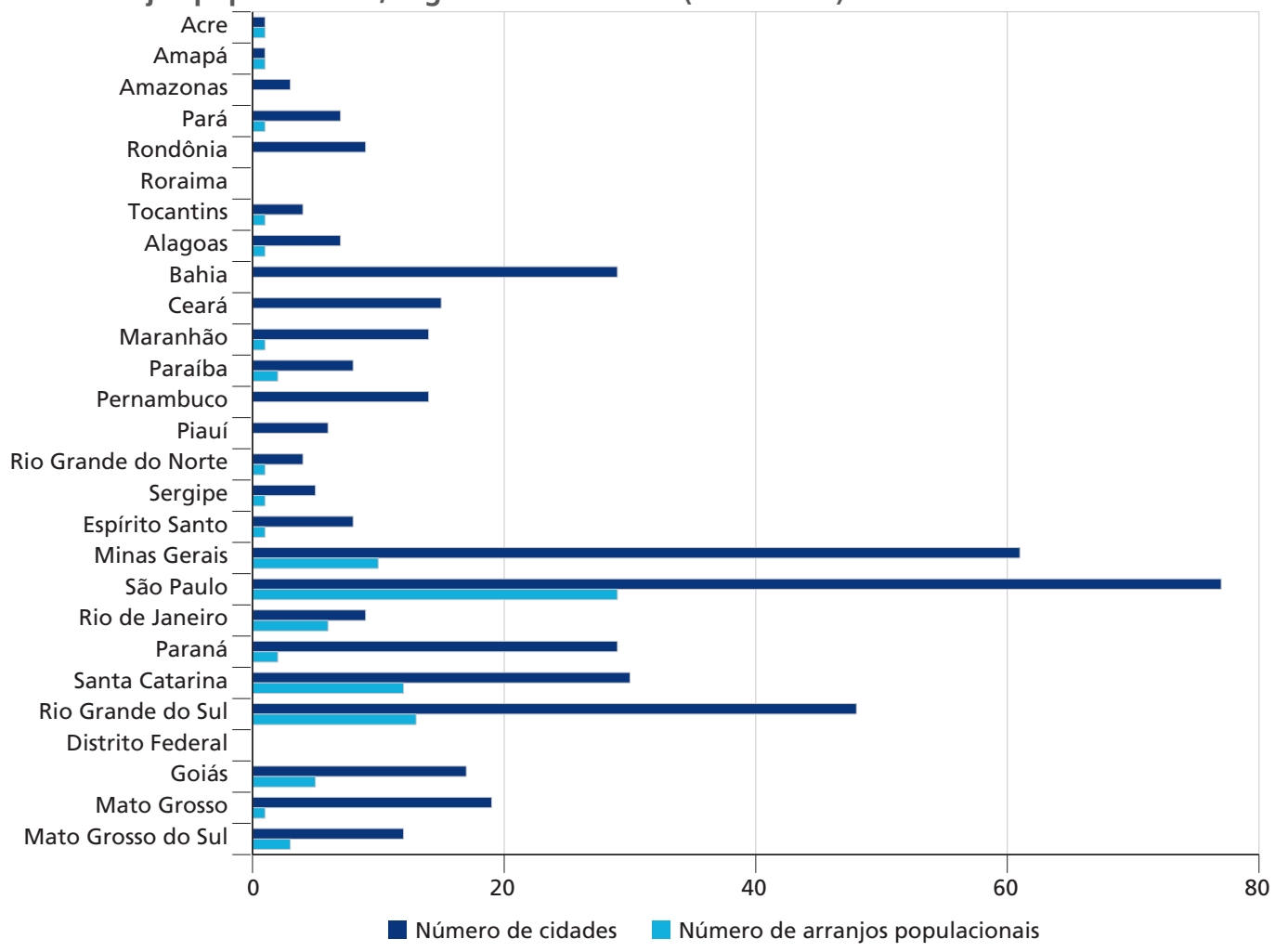

Fonte: IBGE (2020a).

Elaboração: Equipe Fronteiras Ipea. 
A seção que se encerra mostrou que a rede urbana brasileira obedece a um padrão de organização similar desde o século XX, com a consolidação das principais centralidades do nível metropolitano e seu fortalecimento com a agregação de novas metrópoles. Poucas são as mudanças nos demais níveis da escala de classificação dos centros, e as principais se deram nas regióes Sudeste, Sul e Centro-Oeste, nesta provocadas fundamentalmente pela criação de novos estados, que têm o posicionamento privilegiado na hierarquia pelo exercício da gestão do território.

A grande mudança a ser registrada na rede urbana brasileira deve-se a que as centralidades já não correspondem a municípios. As cidades classificadas pelo IBGE, desde a pesquisa de 2007, correspondem muitas vezes a unidades urbanas formadas por conjuntos de municípios ou APs. Essas cidades formam as principais centralidades dos níveis metropolitano e das capitais regionais, mas destaca-se que se encontram também entre os centros sub-regionais e de zonas, nas cinco grandes regióes brasileiras. Como essas centralidades correspondem, em grande medida, às que obtiveram elevação no nível classificatório no período, infere-se que a sinergia desse conjunto aponta para positividades que merecem ser melhor exploradas de modo a subsidiar o planejamento e as propostas para políticas públicas de desenvolvimento regionais.

\section{AS RELAÇÕES INTERNACIONAIS DA REDE URBANA}

Um avanço relevante da pesquisa Regic 2018 se deu na análise das relaçóes internacionais das cidades brasileiras, sejam aquelas medidas na capacidade de atração das cidades da faixa de fronteira terrestre, ${ }^{17}$ sejam as interconectividades avaliadas pela presença de firmas e serviços avançados nas cidades brasileiras. No primeiro caso, os resultados colhidos na pesquisa de 2018 foram relevantes ao projeto em curso no Ipea, A PNDR e a faixa de fronteira, pela confirmação e qualificação das ligaçóes entre cidades fronteiriças, assim como pelo alcance territorial dessas ligaçôes, evidenciando as principais motivaçóes e a dimensão espacial das relaçóes transfronteiriças. No segundo caso, a pesquisa do IBGE identifica empresas com presença global quanto a serviços avançados, ramos de atuação, e tipo de incidência nas cidades, desde uma atuação local até extralocal e a presença de

17. Estabelecida pela Lei no 6.634, de 2 de maio de 1979, contemplava, na época da pesquisa, 588 municípios brasileiros com área total ou parcialmente localizada na faixa interna de $150 \mathrm{~km}$ de largura, paralela à linha divisória terrestre do território nacional. 
sedes. Nos dois casos, os resultados da pesquisa tornam claros os principais links internacionais, sua área de influência e confirmam a importância da hierarquia urbana em reproduzir os padróes de conectividade internacional.

\subsection{Ligações internacionais a partir da faixa de fronteira terrestre}

No papel de fornecedoras de bens e serviços, algumas cidades brasileiras possuem uma atratividade que transcende as fronteiras nacionais, servindo também a residentes dos países vizinhos, cuja busca gera fluxos contínuos de pessoas em comutação. Para identificar as origens, os motivos e os graus de atratividade das cidades da faixa de fronteira terrestre, na pesquisa Regic 2018, foi aplicado um questionário específico voltado a identificar as ligaçôes internacionais desses municípios. Movimentos no sentido oposto, do Brasil para cidades dos países vizinhos também ocorrem, porém não foram contemplados por essa pesquisa. ${ }^{18}$

A coleta dessa informação considerou o conhecimento empírico de responsáveis pelas Agências do IBGE, que responderam "de quais cidades dos países vizinhos são oriundas as pessoas que vêm adquirir bens e serviços no Brasil” (IBGE, 2020a, p. 147). Os bens e serviços considerados foram os mesmos relativos à pesquisa sobre a relaçáo entre cidades brasileiras. No caso das cidades da faixa de fronteira, pesquisou-se a atratividade internacional para: compras de calçados e vestuários, compras de móveis e eletroeletrônicos, serviços de saúde de baixa e média complexidade, serviços de saúde de alta complexidade, ensino superior, atividades culturais, atividades esportivas e uso de aeroportos. O IBGE (2020a, p. 147) salienta que

embora os questionários tenham buscado situaçôes representativas de relaçôes de fronteiras de caráter mais estável, as zonas fronteiriças são caracterizadas por estarem muito sujeitas a lógicas e fluxos de natureza conjuntural, como flutuaçóes no câmbio, por exemplo. O período em que a pesquisa foi realizada pode, dessa forma, influenciar na qualidade e tipo de resposta obtida, refletindo movimentos efêmeros de pessoas buscando bens e serviços através das fronteiras.

18. As informações sobre movimentos pendulares para trabalho e/ou estudo em países estrangeiros, disponibilizados pelo Censo Demográfico de 2010, ofereceram importantes subsídios para análises de fluxos com destino a outros países e, apesar de não terem sido pesquisados na direção inversa (de estrangeiros com destino aos municípios brasileiros), disponibilizam informaações que auxiliam na compreensão da mobilidade transfronteiriças. Em Pêgo e Moura (2018), encontram-se alguns estudos que fazem uso dessa informação. 
As informações colhidas pelo IBGE evidenciaram que a "hinterlândia das cidades brasileiras avança sobre o território dos demais países, sendo referência tanto de cidadáos estrangeiros quanto de brasileiros residentes no exterior para a aquisição de produtos e o usufruto de serviços" (2020a, p. 147). Assim, os muitos motivos das ligaçóes externas de algumas cidades brasileiras a cidades dos países vizinhos desencadeiam fluxos que desenham regiôes de influência que transcendem as fronteiras nacionais, e qualificam as principais centralidades da faixa de fronteira, muitas das quais identificadas como APs fronteiriços (IBGE, 2016) ou APs internacionais, como nominados na última pesquisa (IBGE, 2020a). Na pesquisa de 2018, se observa ainda que a influência de uma cidade ao fornecer bens e serviços é proporcional à distância a partir das fronteiras, ou seja, quanto mais se afasta da fronteira, menor se torna o número de localidades que se relacionam com a cidade. Observa-se também que a quantidade dos relacionamentos é proporcional à densidade de cada porção fronteiriça, possuindo padrôes mais complexos nas fronteiras do Sul que nas do Centro-Oeste e Norte.

Os fluxos direcionados a cidades da faixa de fronteira representam majoritariamente contatos de curta distância (mapa 5), algumas vezes extrapolando os municípios localizados na linha de fronteira. Os fluxos de longa distância, excluídos no gráfico 1 , ocorreram por uma única finalidade no destino, e entre as oito motivaçôes consideradas reportaram-se a três: i) por motivo de ensino superior, entre Bogotá, Caracas, Lima e Quito com os municípios Capão do Leão e Pelotas (RS), entre Lima e Rio Grande (RS), e entre Tacna (Peru) e Sant'Ana do Livramento (RS); ii) por motivo de atividades esportivas, fluxos entre Lima, Quito e Santa Cruz de la Sierra, com Alegrete (RS) e entre Medellín (Colômbia) e Chapecó (SC); e iii) por atividades culturais, unicamente, entre Buenos Aires e Corumbá (MS). 
MAPA 5

Ligações internacionais com destino a municípios da faixa de fronteira terrestre América do Sul (2018)

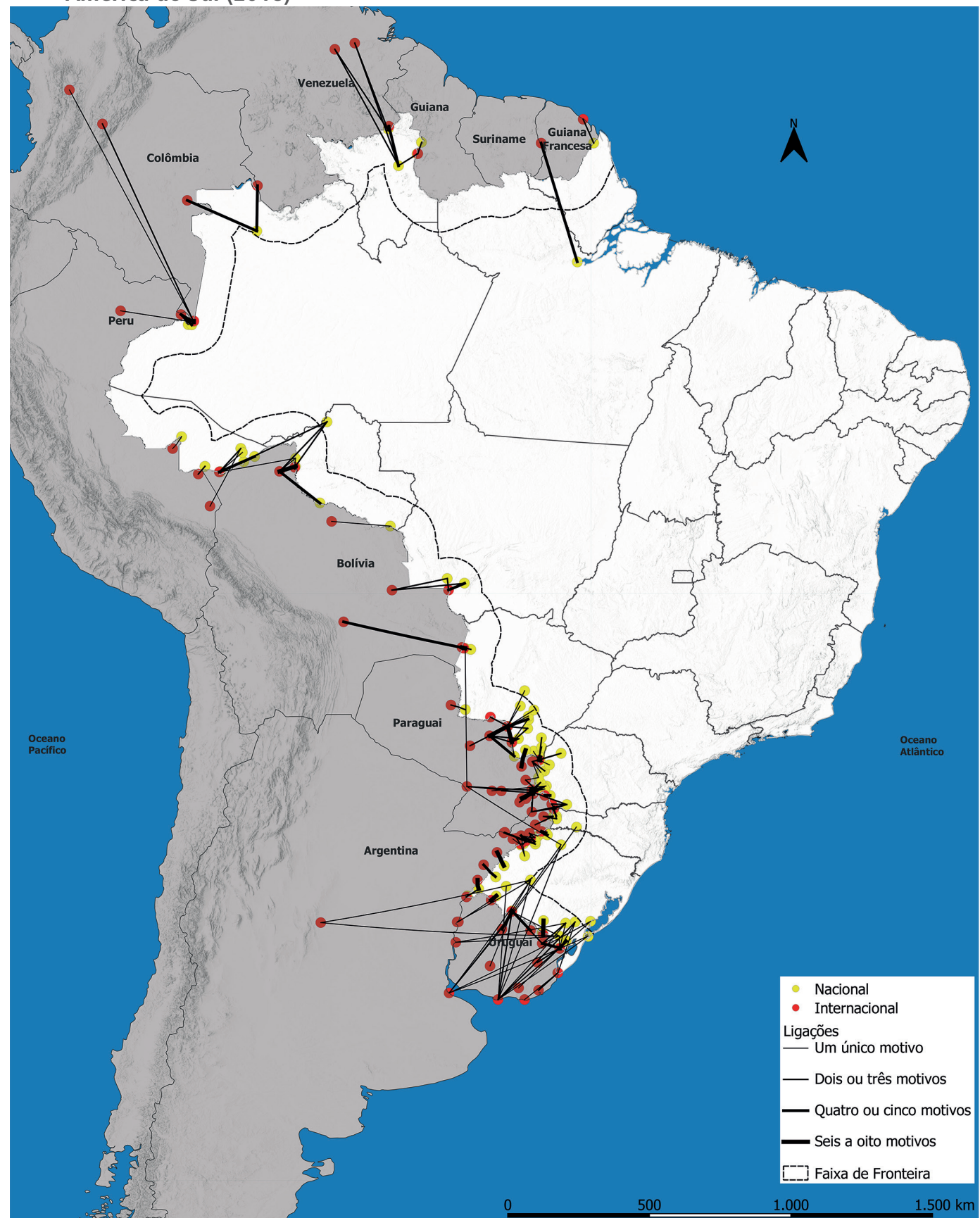

Fonte: IBGE (2020a).

Elaboração: Equipe Fronteiras Ipea.

Obs.: Não foram mapeadas as ligações de longa distância entre: Bogotá - Capão do Leão, Pelotas; Buenos Aires - Corumbá; Caracas - Capão do Leão, Pelotas; Lima - Alegrete Capão do Leão, Pelotas, Rio Grande; Medellín - Chapecó; Quito - Alegrete, Capão do Leão, Pelotas; Santa Cruz de la Sierra - Alegrete; Tacna - Santana do Livramento. 
Além das quinze ligaçôes consideradas de longa distância, 211 destas descrevem fluxos de curta distância, e somadas apontam as 226 ligaçóes internacionais, das quais 75 ocorreram por uma única motivação; 83 por dois ou três motivos; 30 por quatro a cinco motivos; e 23 por seis a oito motivos. Este último conjunto expressa uma forte inteiração transfronteiriça entre as cidades localizadas na linha de fronteira ou, quando não, integradas a algum arranjo transfronteiriço, casos de Bagé (ao arranjo transfronteiriço de Aceguá/RS - Acegua/Uruguai) e Mundo Novo (ao de Guaíra/PR - Salto del Guairá/Paraguai).

As atividades culturais são as principais motivaçôes de ligação entre cidades, tendo aparecido em 22,2\% dos fluxos realizados, sejam de curta ou longa distância; são sucedidas pelo motivo de compra de vestuário ou calçados $(20,4 \%)$ e por busca de serviços de saúde de baixa e média complexidade $(15,3 \%)$ - tabela 8 .

TABELA 8

Motivos de ligações internacionais destinadas a cidades da faixa de fronteira (2018)

\begin{tabular}{lcc}
\hline Motivo do deslocamento & Número de citações & $\begin{array}{c}\text { Sobre o total citado } \\
(\%)\end{array}$ \\
\hline Atividades culturais & 125 & 22,2 \\
Compra de vestuário e calçados & 115 & 20,4 \\
Serviços de saúde de baixa e média complexidades & 86 & 15,3 \\
Compra de móveis e eletroeletrônicos & 76 & 13,5 \\
Atividades esportivas & 64 & 11,4 \\
Ensino superior & 40 & 7,1 \\
Serviços de saúde de alta complexidade & 37 & 6,6 \\
Aeroporto & 20 & 3,6 \\
Total & 563 & 100 \\
\hline \multicolumn{1}{c}{ Fonte: IBGE (2020a). } & &
\end{tabular}

\subsection{Conexões de longa distância}

Também houve um refinamento em relação às informaçóes utilizadas para avaliar as conexôes internacionais de longa distância, "dada pelas redes empresariais de companhias que se multilocalizam em diversos países e que têm, em cidades brasileiras, nós importantes para seu funcionamento" (IBGE, 2020a, p. 148). Para efeitos da pesquisa sobre como a rede urbana brasileira se articula internacionalmente, com base em Taylor, 
Hoyler e Verbruggen (2010), o IBGE (2020a, p. 149) considerou entre os critérios para a definição dos agentes geradores de rede

a capacidade de exportar serviços para além do mercado local como principal indicador as firmas de serviços avançados", que "são aquelas capazes de prestar auxílio às atividades produtivas, como os principais atores econômicos, criando conexóes das economias urbanas entre si. Isso se dá porque as Cidades permitem o surgimento de uma massa crítica de firmas que geram um ambiente de conhecimento propício para seu funcionamento.

Foi feita uma seleção de 29 empresas de serviços avançados nos setores de tecnologia da informação (TI), desenvolvimento de software, advocacia, publicidade e marketing, arquitetura, economia digital que possuem atuação internacional, sede em país estrangeiro e escritório no Brasil ou vice-versa (tabela 9). ${ }^{19}$

TABELA 9

Empresas de serviços avançados selecionadas para as ligações internacionais (2018)

\begin{tabular}{lllc}
\hline Empresa & \multicolumn{1}{c}{ Ramo } & País-sede & Cidades \\
\hline SAP & Serviços de TI e gestão empresarial & Alemanha & 182 \\
Accenture & Serviços de TI & Irlanda & 173 \\
Capgemini & Serviços de Tl e gestão empresarial & França & 166 \\
Ogilv \& Mather & Publicidade e marketing & Estados Unidos & 105 \\
CA Technologies & Software corporativo & Estados Unidos & 104 \\
JWT & Publicidade e marketing & Estados Unidos & 91 \\
Leo Burnett & Publicidade e marketing & Estados Unidos & 91 \\
Y\&R & Publicidade e marketing & Estados Unidos & 87 \\
Havas & Publicidade e marketing & França & 86 \\
Westcon & Serviços de TI & Estados Unidos & 81 \\
Teleperformance & Gestão de negócios & França & 73 \\
Mullenlowe & Publicidade e marketing & Estados Unidos & 70 \\
Publicis & Publicidade e marketing & França & 60 \\
ATENTO & Serviços de TI & Espanha & Briqus \\
Experian & Certificados digitais e consultoria financeira & Irlanda & 51 \\
TOTVS & Serviços de TI & Brasil & 51 \\
Siqueira Castro & Advocacia & Brasil & 39 \\
Décio Freire Advogados & Advocacia & & 22 \\
\hline
\end{tabular}

19. Para essa escolha, foram consultados vários rankings de classificação de empresas ou agências de serviços avançados, alguns considerados na edição de 2007 da Regic. Para mais informações e fontes, ver IBGE (2020a, p. 149). 


\begin{tabular}{|c|c|c|c|}
\hline Empresa & Ramo & País-sede & Cidades \\
\hline TIVIT & Serviços de TI & Brasil & 19 \\
\hline Valid & identificação & Brasil & 16 \\
\hline Sonda & Serviços de TI & Chile & 10 \\
\hline Noronha Advogados & Advocacia & Brasil & 8 \\
\hline TozziniFreire & Advocacia & Brasil & 7 \\
\hline Arruda Alvim \& Thereza Alvim & Advocacia & Brasil & 5 \\
\hline Demarest Advogados & Advocacia & Brasil & 5 \\
\hline Mattos Filho & Advocacia & Brasil & 5 \\
\hline Choaib, Paiva e Justo & Advocacia & Brasil & 3 \\
\hline PSQA & Advocacia & Brasil & 3 \\
\hline Studio Arthur Casas & Arquitetura & Brasil & 2 \\
\hline
\end{tabular}

Fonte: IBGE (2020a, tabela 41, p. 150).

Como aponta o IBGE, o conjunto de empresas analisadas, "desde grandes multinacionais com presença em todos os continentes, até firmas presentes em alguns pares de cidades", é uma amostra de firmas de serviços avançados que operam no país e suas ligações além das fronteiras. Aponta ainda que:

O objetivo dessa análise não é estudar a rede de empresas e cidades globais em si, mas caracterizar a forma pela qual as cidades brasileiras se inserem na economia global a partir da atuação de um grupo de empresas transfronteiriças. Dessa maneira, tem-se a consciência de que o grupo de firmas selecionadas se encontra enviesado, o que amplifica a representatividade da rede urbana nacional. O intuito é enfatizar a atuação das atividades localizadas nas cidades brasileiras (IBGE, 2020a, p. 150).

Os resultados constatam que as principais interconexões se deram com a Europa Ocidental, sobretudo com Paris (França), Lisboa (Portugal), Dublin (Irlanda) e Estados Unidos, particularmente Nova Iorque. Na América do Sul, os vínculos mais fortes se deram com Buenos Aires (Argentina), Santiago (Chile) e Bogotá (Colômbia).

Internamente ao Brasil, os resultados dessa pesquisa reiteram a "importância da hierarquia urbana em reproduzir os padrôes de conectividade internacional” (IBGE, 2020a, p. 150). A grande metrópole nacional formada pelo AP de Sáo Paulo funciona como "relé" para a maioria das ligaçóes internacionais, ou seja, como intermediária à ligação da maior parte das cidades brasileiras ao restante do mundo. A metrópole nacional formada pelo AP do Rio de Janeiro se destaca por sediar algumas das empresas 
selecionadas e desenvolver ligações diretas com cidades estrangeiras. Entre os demais destaques estão a metrópole nacional formada pelo AP de Brasília e as metrópoles formadas pelos APs de Belo Horizonte, Salvador, Recife, Curitiba e Porto Alegre. Fora das capitais de UFs, a maioria das cidades significativas, do ponto de vista das redes globais, concentra-se na região Sudeste.

Esses resultados reforçam a importância desse conjunto de metrópoles e cidades, que além de se configurar como área de concentração de população abriga ativos econômicos, técnico-científicos, do conhecimento e informaçáo, e infraestruturas. Segundo Santos (1996), há nessa região as condiçôes mais avançadas de realização e transformação do espaço, dada a constituiçáo do que se denomina um meio técnico-científico-informacional, do qual emana não só a renda e a capacidade de produção e circulação dos produtos, como o conhecimento, a informação e os meios de exercício do comando ao restante do território.

Isso explica, de certa maneira, porque as mudanças nos níveis de classificação superior da hierarquia urbana se mantêm, tendo como localização das principais centralidades essa porção do território. Reforçando essa permanência, agregam lentamente outras cidades do mesmo espaço, que aos poucos vão constituindo as condiçóes de participarem ativamente dessa região ampliada, densa e poderosa do território nacional.

\section{CONSIDERAÇÕES FINAIS}

Procurou-se neste texto destacar alguns resultados da pesquisa realizada e disponibilizada pelo IBGE sobre as Regióes de Influência das Cidades 2018, comparativamente às demais da série, e tecer alguns comentários sobre as principais constataçôes a partir de sua leitura. Essa série de pesquisa vem, desde os anos 1960, oferecendo preciosas informaçóes quanto ao estabelecimento das hierarquias e dos vínculos entre cidades, e a delimitação das suas áreas de influência. Ademais, traz textos ricos em conteúdo

e informaçôes a serem processadas a partir de dados secundários, além de um acervo cartográfico que conta a história das reconfiguraçôes e dos reescalonamentos na hierarquia da rede urbana brasileira. 
Sublinha-se a relevância que reveste a inserção da pesquisa mais recente à série de estudos sobre as centralidades urbanas, por atualizar a organização da rede e incorporar as transformaçôes da urbanização destas décadas iniciais do século XXI. Com mais este produto, a série torna-se ainda mais merecedora de ser valorizada por se constituir no único trabalho da América do Sul voltado a acompanhar a evolução da rede urbana de um país, com elevado nível de detalhamento. Para além e apesar de todos os reveses pelos quais passa a pesquisa no Brasil, particularmente no âmbito governamental, manteve-se uma sistematicidade elogiável, aprimorando os procedimentos operacionais sem comprometer a comparabilidade metodológica nem os resultados, o que garantiu fidelidade ao objetivo da pesquisa e confiabilidade em seus resultados.

O conjunto formado pelas informaçôes, análises intermediárias, escalas classificatórias e delimitação da abrangência da influência das cidades contribui, sobremaneira, para a definição de políticas públicas (urbanas, regionais, territoriais), para a pesquisa acadêmica e para a tomada de decisóes no âmbito de empresas e investidores. A sociedade conta, para tanto, com informaçôes de qualidade, disponibilizadas ao público no portal da instituição, com possibilidade de fácil e ilimitado acesso. Basta que se queira consultar tais dados.

Neste texto, foram salientadas as mais notáveis transformaçôes da rede urbana registradas na última pesquisa, assim como realizada uma análise da variaçâo da classificação das cidades na hierarquia urbana, desde a primeira pesquisa. Variação esta que aponta para a tendência de reforço de uma hierarquia que vem se consolidando desde meados do século passado, a partir da permanência das centralidades metropolitanas em suas devidas posiçóes e da agregação de novas metrópoles a esse conjunto, fortalecendo o comando da organização do território. Vê-se configurada uma rede urbana mais densa, com mais elos entre cidades de distintas regióes, mais ramificada e com maior capacidade de penetrar no interior do território e alcançar as fronteiras nas áreas de menor densidade do país.

A variação no escalonamento dos centros, como expressão da trajetória da rede urbana a partir da década de 1960, sintetiza-se em duas palavras: permanência, notada na estabilidade da posição de um grande número de cidades nos mesmos níveis hierárquicos da rede, ou sob pequenas oscilaçôes que não implicaram mudança de nível. Esta relativa à elevação ou queda nos reescalonamentos ao longo do período. A mudança corresponde a um número menor de cidades e se reparte entre as que galgam novas 
condiçôes de funcionalidade e por isso se reposicionam em níveis superiores, e aquelas que por inúmeros motivos, como decadência ou perda relativa de importância regional, declinam em seu posicionamento na escala hierárquica da rede urbana. Ambos os casos requerem análise em detalhe que explique os comportamentos gerais e específicos aos diferentes contextos urbanos e regionais do país.

Entre os aprimoramentos metodológicos e operacionais, ressalta-se a consolidação do entendimento de cidade enquanto uma unidade espacial que pode se constituir tanto por apenas um município quanto por um conjunto de municípios que se agregam em um arranjo populacional, que transcende limites político-administrativos e, em alguns casos, fronteiras internacionais. Tais unidades são a evidência de processos socioespaciais que resultam em configuraçóes aglomeradas e expandidas, características da metropolizaçáo contemporânea, que ainda enfrentam grande dificuldade de serem assim compreendidas e consideradas como objetos de análise e de intervenção pública.

Esse entendimento deve ser sublinhado como um avanço elogiável e de grande ousadia, pois implica se recolocar em discussão as limitaçóes que o sistema federativo brasileiro impóe para a gestão urbana de espaços em aglomeraçôes plurimunicipais: um sistema aberto ao intento de fragmentação do território e refratário e dificultoso à institucionalização de alternativas de agremiação de unidades político-administrativas. Portanto, é imprescindível repensar os instrumentos e mecanismos de gestão para essas formaçóes socioespaciais plurimunicipais, que exigem pactuações e cooperação para o exercício de funçôes públicas de interesse comum, pois os existentes não têm logrado êxito.

Os resultados da pesquisa Regic 2018 trazem também o ineditismo da análise das relaçóes internacionais entre as cidades brasileiras e as de outros países, para o que considerou tanto as ligaçóes de curta distância, entre centros de países vizinhos, atraídos por cidades da faixa de fronteira terrestre, quanto as conexôes de longa distância movidas por empresas nacionais e/ou estrangeiras com atuaçáo internacional. No caso das primeiras, mais uma vez se evoca a importância de se repensar o pacto federativo e os acordos bi e trinacionais, para a gestão de cidades que se acomodam sobre as linhas de fronteiras. Tais cidades, ou arranjos espaciais internacionais plurimunicipais, têm invisibilizada a dimensão de relaçóes efetivamente transfronteiriças, originada a partir das interaçốes cotidianas de sua população e da produção de um espaço híbrido, mesclado por diferentes culturas. 
Consolidada enquanto uma relevante pesquisa, seus resultados também ganharam visibilidade nas estratégias de enfrentamento à pandemia do novo coronavírus. Por um lado, deram mostras da importância de uma rede hierarquizada na organização para prestação de serviços especializados, por outro, apontaram a fragilidade das centralidades principais quanto às condiçóes de atendimento por serviços de alta complexidade. Em algumas regióes, como a Norte e a Centro-Oeste, evidenciaram as limitaçóes na possibilidade de acesso ao atendimento por esses serviços, pelas precárias condiçóes de deslocamento para acesso aos serviços.

Para um futuro próximo, apenas como sugestáo complementar, o produto disponibilizado pelo IBGE precisaria atualizar os dados de classificação das concentraçóes urbanas em grandes e médias concentraçôes de população, algumas alteradas em função da redefinição de determinados APs. Sugere-se, também, redefinir os APs internacionais, que náo incluem alguns importantes arranjos transfronteiriços, como Tabatinga (AM)/Leticia (Colômbia) ou Pacaraima (RR)/Santa Elena de Uairén (Venezuela), embora suas ligaçóes internacionais estejam reconhecidas nos dados divulgados. Os resultados instigam ainda a atualização da regionalização do território, seja pela compatibilização entre as regiōes geográficas imediatas e intermediárias e as regiōes de influência das cidades, conforme delimitação de 2018, seja pela reinserção das regiôes de articulação ampliada, um nível importante para a pesquisa e gestão pública e que pode, ou não, sofrer modificações dada a elevação do número de metrópoles e capitais regionais na rede urbana nacional.

Por fim, este texto oferece uma leitura de elementos destacados da pesquisa do IBGE. Espera-se, com tais apontamentos, provocar questôes, despertar interesse em novas análises e desdobramentos em novas pesquisas, motivar a busca de respostas a determinados comportamentos e trajetórias, incentivar que se explore a especificidade das dinâmicas urbanas e regionais que impulsionam permanências e reposicionamentos escalares na rede urbana, instigar reflexôes sobre as relaçôes entre as cidades brasileiras internamente ao país e com cidades dos países vizinhos, entre outras tantas possibilidades. Além disso, espera-se que esses países se motivem e se espelhem na relevância dos resultados disponibilizados e promovam reflexóes e pesquisas similares, e que o IBGE persista e resista, como historicamente vem fazendo, diante das limitaçóes que poderão ser impostas à continuidade da pesquisa. 


\section{REFERÊNCIAS}

BRANDÃO, A. C. Dinâmicas e transformaçôes territoriais recentes: o papel da PNDR e das políticas públicas não regionais com impacto territorial. In: NETO, A. M. Desenvolvimento regional do Brasil: políticas, estratégias e perspectivas. Rio de Janeiro: Ipea, 2020a.

As ausências e os elos faltantes das análises regionais no Brasil e a proposição de uma agenda de pesquisas de longo prazo. In: NETO, A. M. (Org.). Desenvolvimento regional do Brasil: políticas, estratégias e perspectivas. Rio de Janeiro: Ipea, $2020 \mathrm{~b}$.

BRASIL. Ministério do Planejamento, Orçamento e Gestão. Centro de Gestão e Estudos Estratégicos. Estudo da dimensáo territorial para o planejamento. Brasília: MP, 2008. v. 3.

Presidência da República. Lei no 13.089, de 12 de janeiro de 2015. Institui o Estatuto da Metrópole, altera a Lei no 10.257 , de 10 de julho de 2001, e dá outras providências. Diário Oficial, Brasília, 2015. Disponível em: <https://bit.ly/339XEFV>. Acesso em: 30 nov. 2020.

Presidência da República. Lei no 13.683, de 19 de junho de 2018. Altera as Leis no 13.089, de 12 de janeiro de 2015 (Estatuto da Metrópole), e 12.587, de 3 de janeiro de 2012, que institui as diretrizes da Política Nacional de Mobilidade Urbana. Diário Oficial, Brasília, 2018. Disponível em: <https://bit.ly/33duFko>. Acesso em: 30 nov. 2020.

CHRISTALLER, W. Central places in Southern Germany. New Jersey: Prentice Hall, 1966.

CORRÊA, R. L. A rede urbana. Rio de Janeiro: Ática, 1989.

Rede urbana: reflexóes, hipótese e questionamentos sobre um tema negligenciado.

Cidades, Presidente Prudente, v. 1, n. 1, p. 65-78, 2004.

DINIZ, C. C. A nova configuração urbano-industrial no Brasil. In: KON, A. (Ed.). Unidade e fragmentação: a questão regional no Brasil. São Paulo: Perspectiva, 2002.

Apresentação. In: PEREIRA, R. H. M.; FURTADO, B. A. (Org.). Dinâmica urbano-regional: rede urbana e suas interfaces. Brasília: Ipea, 2011.

EGLER, C. A. G. Mercosul: um território em construção? Revista Ciência e Cultura, São Paulo, v. 58, n. 1, p. 24-28, 2006.

. Apontamentos sobre rede urbana e políticas públicas no Brasil. In: SEMINÁRIO DESIGUALDADES SOCIOESPACIAIS E DESCENTRALIZAÇÃO TERRITORIAL NO BRASIL ATUAL, 2008, Belo Horizonte. Anais... Belo Horizonte: UFMG, 2008. p. 1-24.

. Nodalidade e rede de cidades na América do Sul. Confins, n. 16, 2012. Disponível em: <http://goo.gl/B4h5vO>. Acesso em: 9 ago. 2015. 
EGLER, C. A. G et al. Bases conceituais da rede urbana brasileira: análise dos estudos de referência. In: PEREIRA, R. H. M.; FURTADO, B. A. (Org.). Dinâmica urbano-regional: rede urbana e suas interfaces. Brasília: Ipea, 2011.

GEIGER, P. P. Evolução da rede urbana brasileira. Rio de Janeiro: Centro Brasileiro de Pesquisas Educacionais, 1963.

GONÇALVES, M. F.; BRANDÃO, C. A.; GALVÃO, A. C. F. Regiões e cidades, cidades nas regiões: o desafio urbano-regional. São Paulo: Unesp; Anpur, 2003. 728 p.

IBGE - INSTITUTO BRASILEIRO DE GEOGRAFIA E ESTATÍSTICA. Esboço preliminar da divisão do Brasil em espaços homogêneos e espaços polarizados. Rio de Janeiro: IBGE, 1967. 3 v.

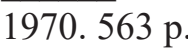

Divisão do Brasil em micro-regiões homogêneas 1968. Rio de Janeiro: IBGE, . Divisão do Brasil em regiões funcionais urbanas. Rio de Janeiro: IBGE, 1972. . Regiões de Influência das Cidades - Regic. Rio de Janeiro: IBGE, 1987.

. Regiões de Influência das Cidades - Regic 1993. Rio de Janeiro: IBGE, 2000. . Regiões de Influência das Cidades - Regic 2007. Rio de Janeiro: IBGE, 2008. . Gestão do território 2014. Rio de Janeiro: IBGE, 2014. 118 p.

. Arranjos populacionais e concentrações urbanas no Brasil. 2. ed. Rio de Janeiro: IBGE, 2016. 167 p.

. Ligações rodoviárias e hidroviárias 2016. Rio de Janeiro: IBGE, 2017. 79 p.

Áreas dos municípios brasileiros. Brasília: IBGE, 2018a. . Estimativas da população residente no Brasil e Unidades da Federação com data de referência em 1ํ de julho de 2018. Rio de Janeiro: IBGE; DPE; Copis, 2018b.

Regiões de Influência das Cidades - Regic 2018. Rio de Janeiro: IBGE, 2020a.

Pesquisa Regiões de Influência das Cidades: informações de deslocamentos para serviços de saúde. Rio de Janeiro, IBGE, 2020 b.

IPARDES - INSTITUTO PARANAENSE DE DESENVOLVIMENTO ECONÔMICO E SOCIAL. Comentários sobre os resultados do Regic 2007. Curitiba: Ipardes, 2009. 34 p.

IPEA - INSTITUTO DE PESQUISA ECONÔMICA APLICADA. Caracterização e tendências da rede urbana do Brasil: configuração atual e tendências da rede urbana no Brasil. Brasília: Ipea, 2001. 
. Configuração atual e tendências da rede urbana do Brasil. Brasília: Ipea, 2002. (Série Caracterização e Tendências da Rede Urbana do Brasil, vários volumes).

. Rede urbana brasileira como agenda de pesquisa no Ipea: retrospecto e perspectivas. Brasília: Ipea, 2016. 82 p. Disponível em: <https://bit.ly/33ftVeJ>. Acesso em: 20 ago. 2020.

LEMOS, M. B; DINIZ, C. C.; GUERRA, L. P. Polos econômicos do Nordeste e suas áreas de influência: uma aplicação do modelo gravitacional utilizando Sistema de Informações Geográficas (SIG). Revista Econômica do Nordeste, v. 30, número especial, p. 568-584, dez. 1999.

MOURA, R.; OLIVEIRA, S. Referências sobre a faixa de fronteira e os arranjos transfronteiriços do Brasil. In: PÊGO, B.; MOURA, R. (Org.). Fronteiras do Brasil: uma avaliação de política pública. Rio de Janeiro: Ipea; MI, 2018, v. 1, cap. 8, p. 243-292.

PÊGO, B.; MOURA, R. (Org.). Fronteiras do Brasil: uma avaliação de política pública. Rio de Janeiro: Ipea; MI, 2018. 453 p. Disponível em: <https://bit.ly/3b2udKi>. Acesso em: 20 jan. 2020.

PEREIRA, R. H. M.; FURTADO, B. A. (Org.). Dinâmica urbano-regional: rede urbana e suas interfaces. Brasília: Ipea, 2011.

SANTOS, B. S. A cruel pedagogia do vírus. Coimbra: Almedina, 2020. Disponível em: $<$ https://bit.ly/3uhBkpK>. Acesso em: 28 ago. 2020.

SANTOS, M. A rede urbana do recôncavo. Salvador: Imprensa Oficial, 1959.

. Crescimento nacional e a nova rede urbana: o exemplo do Brasil. Revista Brasileira de Geografia, v. 29, n. 4, p.78-92, out.-dez. 1967.

. Técnica, espaço, tempo: globalização e meio técnico-científico informacional. São Paulo: Hucitec, 1996.

TAYLOR, P. J. Specification of the world city network. Geographical Analysis, New York, v. 33, n. 2, p. 181-194, Apr. 2001.

TAYLOR, P. J.; HOYLER, M.; VERBRUGGEN, R. External urban relational process: introducing central flow theory to complement central place theory. Sage Journals, v. 47, n. 13, p. 2803-2818, 2010. Disponível em: <https://bit.ly/3nK3KWK>. Acesso em: jan. 2020. 

Ipea - Instituto de Pesquisa Econômica Aplicada

\title{
Assessoria de Imprensa e Comunicação
}

\section{EDITORIAL}

\section{Chefe do Editorial}

Reginaldo da Silva Domingos

\section{Assistentes da Chefia}

Rafael Augusto Ferreira Cardoso

Samuel Elias de Souza

\section{Supervisão}

Camilla de Miranda Mariath Gomes

Everson da Silva Moura

\section{Editoração}

Aeromilson Trajano de Mesquita

Anderson Silva Reis

Cristiano Ferreira de Araújo

Danilo Leite de Macedo Tavares

Jeovah Herculano Szervinsk Junior

Leonardo Hideki Higa

\section{Capa}

Danielle de Oliveira Ayres

Flaviane Dias de Sant'ana

\section{Projeto Gráfico}

Renato Rodrigues Bueno

The manuscripts in languages other than Portuguese published herein have not been proofread.

\author{
Livraria Ipea \\ SBS - Quadra 1 - Bloco J - Ed. BNDES, Térreo \\ 70076-900 - Brasília - DF \\ Tel.: (61) 2026-5336 \\ Correio eletrônico: livraria@ipea.gov.br
}



Composto em adobe garamond pro 12/16 (texto) Frutiger 67 bold condensed (títulos, gráficos e tabelas) Brasilia-DF 



\section{Missão do Ipea}

Aprimorar as políticas públicas essenciais ao desenvolvimento brasileiro por meio da produção e disseminação de conhecimentos e da assessoria ao Estado nas suas decisões estratégicas.

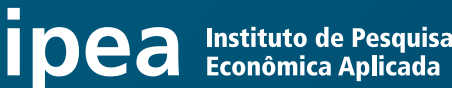 \\ MINISTÉRIO DA \\ ECONOMIA

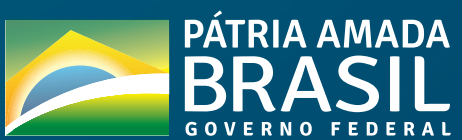

